\title{
Synthesis and Structural Dynamics of Five-Coordinate Rh(III) and Ir(III) PNP and PONOP Pincer Complexes
}

\author{
Thomas M. Hood, Baptiste Leforestier, Matthew R. Gyton, and Adrian B. Chaplin*(]) \\ Department of Chemistry, University of Warwick, Gibbet Hill Road, Coventry CV4 7AL, U.K.
}

Supporting Information

ABSTRACT: The synthesis and characterization of a homologous series of five-coordinate rhodium(III) and iridium(III) complexes of PNP $\left(2,6-\left(t \mathrm{Bu}_{2} \mathrm{PCH}_{2}\right)_{2} \mathrm{C}_{5} \mathrm{H}_{3} \mathrm{~N}\right)$ and PONOP $\left(2,6-\left(t \mathrm{Bu}_{2} \mathrm{PO}\right)_{2} \mathrm{C}_{5} \mathrm{H}_{3} \mathrm{~N}\right)$ pincer ligands are described: $[\mathrm{M}(\mathrm{PNP})(\mathrm{biph})]\left[\mathrm{BAr}_{4}{ }_{4}\right](\mathrm{M}=\mathrm{Rh}, \mathbf{1} \mathbf{a}$; Ir, $\mathbf{1 b}$; biph = 2,2'-biphenyl; $\left.\mathrm{Ar}^{\mathrm{F}}=3,5-\left(\mathrm{CF}_{3}\right)_{2} \mathrm{C}_{6} \mathrm{H}_{3}\right)$ and $[\mathrm{M}$ $(\mathrm{PONOP})(\mathrm{biph})]\left[\mathrm{BAr}_{4}^{\mathrm{F}}\right](\mathrm{M}=\mathrm{Rh}, \mathbf{2 a} ; \mathrm{Ir}, \mathbf{2 b})$. These complexes are structurally dynamic in solution, exhibiting pseudorotation of the biph ligand on the ${ }^{1} \mathrm{H}$ NMR time scale $\left(\Delta G^{\ddagger} \mathrm{ca} .60 \mathrm{~kJ} \mathrm{~mol}^{-1}\right)$ and, in the case of the flexible PNP complexes, undergoing interconversion between helical and puckered pincer ligand conformations $\left(\Delta G^{\ddagger}\right.$ ca. $\left.10 \mathrm{~kJ} \mathrm{~mol}^{-1}\right)$. Remarkably, the latter is sufficiently facile that it persists in the solid state, leading to temperature-dependent disorder in the associated X-ray crystal structures. Reaction of $\mathbf{1}$ and $\mathbf{2}$ with $\mathrm{CO}$ occurs for the iridium congeners $\mathbf{1 b}$ and $\mathbf{2 b}$, leading to the formation of sterically congested carbonyl derivatives.
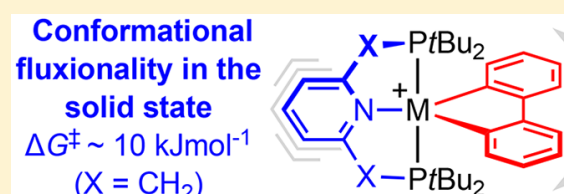

2,2'-Biphenyl

pseudorotation

in solution

$\Delta G^{\ddagger} \sim 60 \mathrm{kJmol}^{-1}$

$\left(\mathrm{X}=\mathrm{CH}_{2}, \mathrm{O}\right)$

$M=R h, I r$

\section{INTRODUCTION}

Pincers are a prominent ligand class in organometallic chemistry and catalysis, conferring thermal stability while permitting a wide range of metal-based reactivity. ${ }^{1}$ As prospective intermediates in stoichiometric and catalytic reactions, the structure and reactivity of five-coordinate rhodium(III) and iridium(III) derivatives are of fundamental mechanistic interest, although the inherent high reactivity of these species can preclude isolation. ${ }^{2,3}$ Coupled with these difficulties, the capacity of coordinatively unsaturated pincer complexes for rapid structural dynamics can encumber accurate structural elucidation in solution and, correspondingly, mechanistic interpretation of any ensuing onward reactivity. In general terms, the associated dynamics can be deconvoluted into (a) pincer ligand-centered processes and (b) pseudorotation of the reactive ligands about the metal (Scheme 1). In the context of the former, atropisomerism of

Scheme 1. Structural Dynamics of Five-Coordinate DED Pincer Complexes in Solution ${ }^{a}$

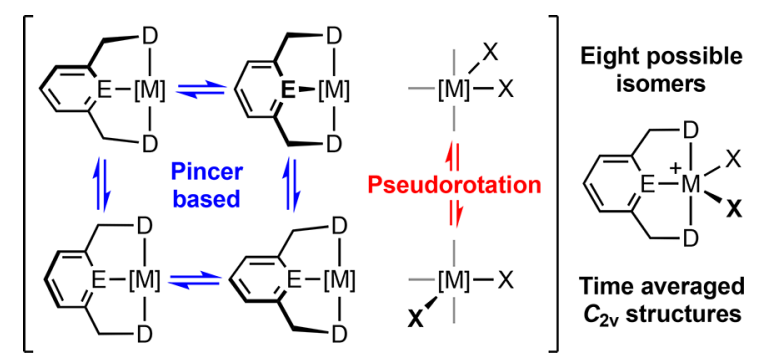

${ }^{a} \mathrm{M}=\mathrm{Rh}, \mathrm{Ir} ; \mathrm{E}=\mathrm{N}, \mathrm{C}^{-} ; \mathrm{X}=$ high trans influence, reactive anionic ligand. the characteristically $C_{2}$ twisted geometries of methylenebridged DED ligands is particularly noteworthy and has been studied in detail for late transition metal complexes of NHCbased CEC ligands. ${ }^{4,5}$ Catalytically important iridium(III) dihydride complexes of phosphine-based pincer ligands are prominent fluxional group 9 examples, exhibiting timeaveraged $C_{2 v}$ symmetry in solution, both for flexible PEP (i.e., (a) + (b) dynamics) and rigid POEOP (i.e., (b) dynamics) pincer ligands. ${ }^{6,7}$

As a platform to systematically study the dynamic properties of low-coordinate group 9 pincer complexes, we herein report on the synthesis, characterization, and reactivity of a new homologous series of five-coordinate rhodium(III) and iridium(III) 2,2'-biphenyl (biph) complexes of flexible PNP $\left(2,6-\left(t \mathrm{Bu}_{2} \mathrm{PCH}_{2}\right)_{2} \mathrm{C}_{5} \mathrm{H}_{3} \mathrm{~N}\right)$ and rigid PONOP (2,6$\left.\left(t \mathrm{Bu}_{2} \mathrm{PO}\right)_{2} \mathrm{C}_{5} \mathrm{H}_{3} \mathrm{~N}\right)$ pincer ligands: $[\mathrm{M}(\mathrm{PNP})(\mathrm{biph})]\left[\mathrm{BAr}_{4}^{\mathrm{F}}\right]$ $\left(\mathrm{M}=\mathrm{Rh}, \mathbf{1} \mathbf{a} ; \mathrm{Ir}, \mathbf{1 b} ; \mathrm{Ar}^{\mathrm{F}}=3,5-\left(\mathrm{CF}_{3}\right)_{2} \mathrm{C}_{6} \mathrm{H}_{3}\right)$ and $[\mathrm{M}(\mathrm{PONOP})(\mathrm{biph})]\left[\mathrm{BAr}_{4}^{\mathrm{F}}\right](\mathrm{M}=\mathrm{Rh}, \mathbf{2 a}$; Ir, 2b; Chart 1$)$. As part of ongoing work in our laboratories exploring the organometallic chemistry of NHC-based pincers, ${ }^{8}$ we have recently prepared CNC analogues $\mathbf{A}$ and $\mathbf{B} .{ }^{9}$ In these complexes, biph pseudorotation is inhibited by the macrocyclic CNC pincer ligand, but slow atropisomerism on the ${ }^{1} \mathrm{H}$ NMR $(600 \mathrm{MHz})$ time scale was established using experiments that detect magnetization transfer. As further precedent, fivecoordinate iridium(III) 2,2'-biphenyl complexes of neutral PCP complexes (C, D) have previously been reported by Krogh-Jespersen, Goldman, and co-workers. ${ }^{10,11}$

Received: April 2, 2019

Published: May 22, 2019 
Chart 1. Rhodium and Iridium Pincer Complexes of 2,2'Biphenyl $^{a}$
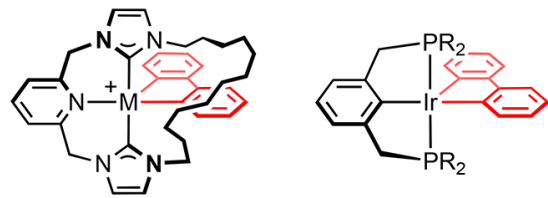

$M=\operatorname{Rh}(\mathbf{A}), \operatorname{Ir}(\mathbf{B})$

$\mathrm{R}=t \mathrm{Bu}(\mathbf{C}), i \operatorname{Pr}(\mathbf{D})$
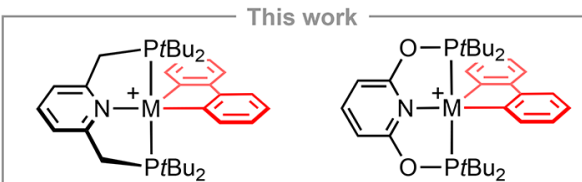

$M=\operatorname{Rh}(\mathbf{1} \mathbf{a}), \operatorname{Ir}(\mathbf{1} \mathbf{b})$

$M=\operatorname{Rh}(\mathbf{2} \mathbf{a}), \operatorname{Ir}(\mathbf{2} \mathbf{b})$

${ }^{a}\left[\mathrm{BAr}_{4}^{\mathrm{F}}\right]^{-}$counter anions omitted for clarity.

\section{RESULTS AND DISCUSSION}

Exploiting precursors first described by Jones and Crabtree ${ }^{12}$ and procedures developed in our laboratories, ${ }^{9,13}$ synthesis of the target PNP and PONOP derivatives $\mathbf{1}$ and $\mathbf{2}$ was achieved through reactions of $[\mathrm{Rh}(\mathrm{biph})(\mathrm{dtbpm}) \mathrm{Cl}](\mathrm{dtbpm}=\mathrm{bis}(\mathrm{di}-$ tert-butylphosphino)methane) or $[\mathrm{Ir}(\mathrm{biph})(\mathrm{COD}) \mathrm{Cl}]_{2}(\mathrm{COD}$ $=1,5$-cyclooctadiene) with the desired pincer ligand in $\mathrm{CH}_{2} \mathrm{Cl}_{2}$ solution in the presence of $\mathrm{Na}\left[\mathrm{BAr}_{4}^{\mathrm{F}}\right]$ as a halide abstracting agent (Scheme 2). ${ }^{14}$ The resulting five-coordinate complexes were all isolated as microcrystalline materials of high purity in good to excellent yield (79-87\%) and extensively characterized in solution and the solid state (vide infra). Employment of this procedure notably avoids the need for late-stage $\mathrm{C}-\mathrm{C}$ bond activation of biphenylene or double $\mathrm{C}-\mathrm{H}$ bond activation of biphenyl associated with the formation of $\mathbf{C}$ and $\mathbf{D}^{10,11}$ and moreover benefits from the use of common and more widely applicable $\mathrm{Rh}(\mathrm{III})($ biph) and $\operatorname{Ir}(\mathrm{III})($ biph) precursors.

Scheme 2. Synthesis of $\mathrm{Rh}(\mathrm{III})$ and $\mathrm{Ir}$ (III) PNP and PONOP Complexes 1 and $2^{a}$

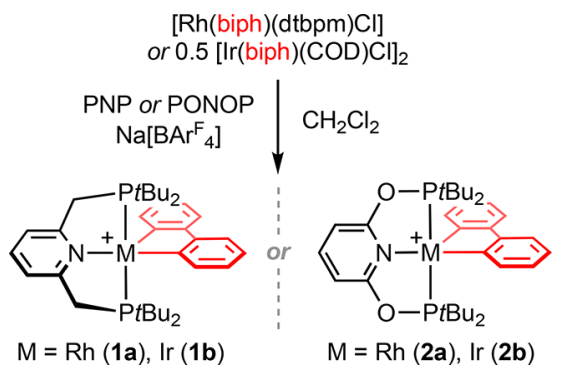

${ }^{a}\left[\mathrm{BAr}_{4}^{\mathrm{F}}\right]^{-}$counter anions omitted for clarity.

Single crystalline samples of $\mathbf{1}$ and $\mathbf{2}$ suitable for interrogation by X-ray diffraction were obtained in all cases, with the homologous metal pairs $\mathbf{1} \mathbf{a}, \mathbf{b}$ and $\mathbf{2} \mathbf{a}, \mathbf{b}$ being isomorphous. The structures of $\mathbf{1 b}$ and $\mathbf{2} \mathbf{b}$ (determined at $150 \mathrm{~K}$ ) are shown in Figure 1, with key metrics for the complete set provided in Table 1. The solid-state structures are notable for pseudosquare pyramidal metal geometries about the metal, with nearideal $\mathrm{N} 20-\mathrm{M}-\mathrm{C} 15$ but distinctly obtuse $\mathrm{P} 2-\mathrm{M} 1-\mathrm{P} 3$ angles $\left(1\right.$, ca. $164^{\circ} ; 2$, ca. $\left.160^{\circ}\right)$. In each case, one of the tert-butyl substituents is canted toward the vacant coordination site and characterized by $\underline{\mathrm{M} 1} \cdots \mathrm{H}-\underline{\mathrm{C} 29}$ contacts of $3.001(3)-3.072(3)$ $\AA$ and reduced $\mathrm{M} 1-\mathrm{P} 2-\mathrm{C} 28$ angles of 104.11(9)$107.05(10)^{\circ}$. These features mark out the formation of weak agostic interactions, ${ }^{15}$ decreasing in the order $\mathbf{1 b}>\mathbf{1 a}>\mathbf{2 b}>$ $\mathbf{2 a}$, although contrasting those observed for $\mathbf{A}$ and $\mathbf{B}(\underline{\mathrm{M}} \cdots \mathrm{H}-$ $\underline{C}$ contacts of $2.978(5)-3.000(3) \AA$ ), meaningful $3 c-2 e$ bonding was not substantiated by ATR IR spectroscopy. Consistent with these experimental observations, natural bond orbital (NBO) analysis of optimized geometries of $\mathbf{1}$ and $\mathbf{2}$ indicates the associated NBO perturbation energies are considerably less than those in $\mathbf{A}$ and $\mathbf{B}$ and of very low absolute magnitude $\left(\sum \Delta E^{2} / \mathrm{kJ} \mathrm{mol}^{-1}: 1 \mathrm{a}, 26.8 ; 1 \mathbf{b}, 42.3 ; 2 \mathrm{a}\right.$, $11.0 ; 2$ b, 22.0; cf. A, 79.3; B, 107.9; see the Supporting Information). ${ }^{9,16}$ On the basis of these data, the yawing of the phosphine donors is therefore best reconciled by steric buttressing between the biph ligand and the proximal tertbutyl substituents rather than a consequence of agostic bonding with the metal. Coordination of biph is associated with a disparity between the $\mathrm{M} 1-\mathrm{C} 4$ and $\mathrm{M} 1-\mathrm{C} 15$ bond lengths (ca. $3 \mathrm{pm}$ ) expected for the presence of an open coordination site trans to the former.

Close inspection of the solid-state structures of $\mathbf{1}$ determined at $150 \mathrm{~K}$ revealed the presence of minor disordered components that could be satisfactorily modeled as conformational isomers, where the pincer is coordinated in a puckered $C_{s}$ symmetric manner (conferring overall $C_{s}$ symmetry; $1-C_{s}$ ) instead of the helical $C_{2}$ symmetry found for the major component (conferring overall $C_{1}$ symmetry; $1-C_{1}$ ). Binding of this nature is not uncommon for platinum group metal PNP pincer complexes ( $22 \%$ frequency, CSD v5.40), with a number of prominent rhodium and iridium examples.,17 Recognizing that this disorder could be the manifestation of structural dynamics in the solid state, ${ }^{18}$ additional crystallographic data were collected across a wide temperature range $(75-250 \mathrm{~K})$, for both the rhodium and iridium congeners, and subsequently refined using a disorder model involving both helical and puckered pincer binding modes (Figure 2). From these data, it can be concluded that dynamic equilibration between these two pincer ligand conformations does indeed occur in the solid state: with the former conformation enthalpically favored and exclusively observed at $75 \mathrm{~K}$ (within the error of the experiment) but entropically disfavored over the latter, which commands a significant fraction of the model at $250 \mathrm{~K}$ (1a, $29 \% ; 1 \mathbf{b}, 33 \%)$.

A van't Hoff analysis of the equilibrium temperature dependence enabled the associated thermodynamic parameters to be extracted: $1 \mathrm{a}, \Delta H=+2.0 \pm 0.1 \mathrm{~kJ} \mathrm{~mol}^{-1}, \Delta S=+0.4 \pm$ $0.9 \mathrm{~J} \mathrm{~K} \mathrm{~mol}^{-1}\left(\Delta G_{298 \mathrm{~K}}=+1.9 \pm 0.4 \mathrm{~kJ} \mathrm{~mol}^{-1}\right) ; \mathbf{1 b}, \Delta H=+2.0$ $\pm 0.1 \mathrm{~kJ} \mathrm{~mol}^{-1}, \Delta S=+1.7 \pm 0.9 \mathrm{~J} \mathrm{~K} \mathrm{~mol}^{-1}\left(\Delta G_{298 \mathrm{~K}}=+1.5 \pm\right.$ $\left.0.4 \mathrm{~kJ} \mathrm{~mol}^{-1}\right)$. No statistically significant differences can be inferred for the congeners, but the trend is for the isomerization to be less endergonic for $\mathbf{1 b}$. This suggestion is supported by a DFT-based computational analysis at the $\omega \mathrm{B} 97 \mathrm{X}-\mathrm{D} 3$ level of theory, ${ }^{19}$ although the calculations are unable to reproduce the relative energetics of the isomers in silico: 1a, $\Delta G_{298 \mathrm{~K}}=-0.7 \mathrm{~kJ} \mathrm{~mol}^{-1} ; 1 \mathrm{~b}, \Delta G_{298 \mathrm{~K}}=-2.1 \mathrm{~kJ}$ $\mathrm{mol}^{-1}$. More importantly, the calculations affirm a very small energy difference between the alternative ligand conformations with low associated activation barriers (1a, $\Delta G^{\ddagger}=8.4 \mathrm{~kJ}$ $\mathrm{mol}^{-1}$; $\mathbf{1 b}, \Delta G^{\ddagger}=9.8 \mathrm{~kJ} \mathrm{~mol}^{-1}$ ), congruous with fluxionality in the solid state. Combined, the experimental and computational data suggest that $C_{2}$ and $C_{s}$ symmetric binding of PNP ligands is nearly isoenergetic and rapid interconversion between these 

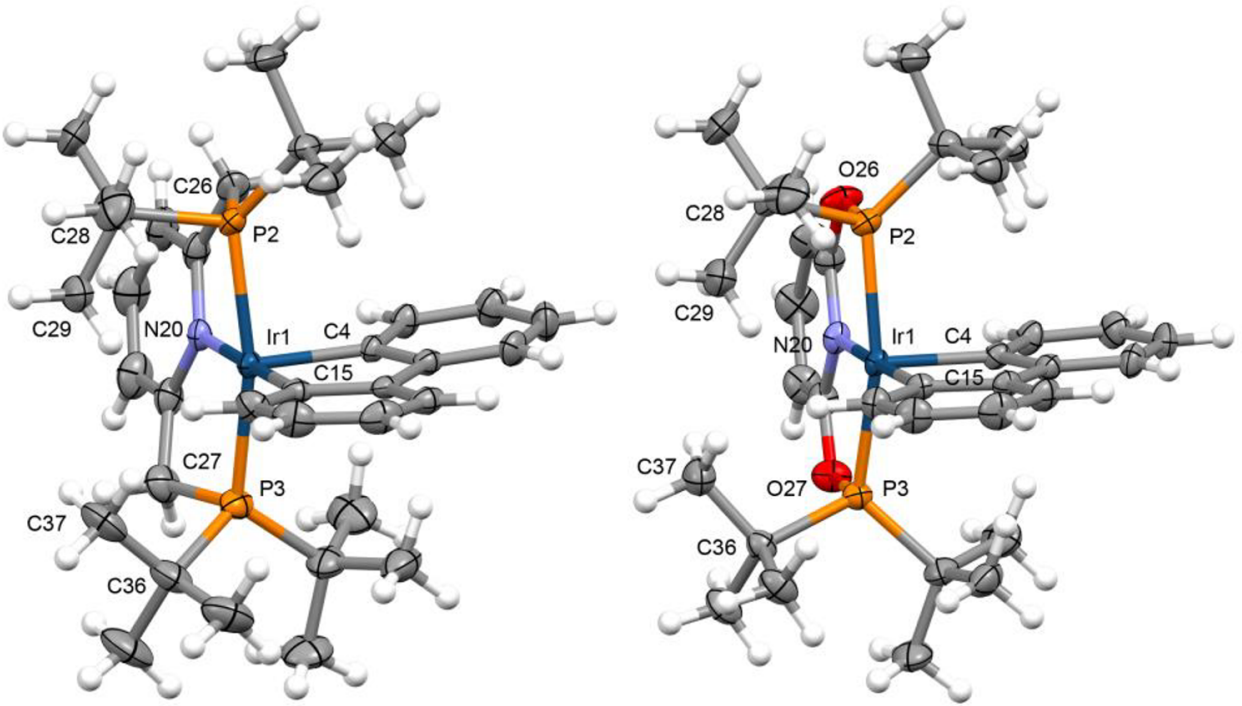

Figure 1. Solid-state structures of $\mathbf{1 b}$ (left) and $\mathbf{2 b}$ (right) determined at $150 \mathrm{~K}$. Thermal ellipsoids drawn at $50 \%$ probability; minor disordered component in $\mathbf{1 b}$, solvent in $\mathbf{2 b}$, and anions omitted.

Table 1. Selected Bond Lengths ( $\AA$ ) and Angles (deg) for 1 and 2 Determined at $150 \mathrm{~K}$

\begin{tabular}{|c|c|c|c|c|}
\hline \multirow[b]{2}{*}{ metric } & \multicolumn{2}{|c|}{$\mathrm{PNP}^{a}$} & \multicolumn{2}{|c|}{ PONOP } \\
\hline & $M=R h(1 \mathbf{a})$ & $M=\operatorname{Ir}(\mathbf{1 b})$ & $M=R h(2 a)$ & $M=\operatorname{Ir}(2 \mathbf{b})$ \\
\hline $\mathrm{M} 1-\mathrm{P} 2$ & $2.3047(6)$ & $2.3076(6)$ & $2.3201(6)$ & $2.3099(7)$ \\
\hline $\mathrm{M} 1-\mathrm{P} 3$ & $2.3797(6)$ & $2.3612(7)$ & $2.3384(6)$ & $2.3326(6)$ \\
\hline $\mathrm{M} 1-\mathrm{N} 20$ & $2.130(2)$ & $2.123(2)$ & $2.096(2)$ & $2.096(2)$ \\
\hline $\mathrm{M} 1-\mathrm{C} 4$ & $1.988(2)$ & $2.001(2)$ & $1.996(2)$ & $2.013(2)$ \\
\hline $\mathrm{M} 1-\mathrm{C} 15$ & $2.023(2)$ & $2.040(2)$ & $2.021(2)$ & $2.044(2)$ \\
\hline M1-C29 & $3.025(3)$ & $3.001(3)$ & $3.072(3)$ & $3.031(3)$ \\
\hline $\mathrm{P} 2-\mathrm{M} 1-\mathrm{P} 3$ & $164.49(2)$ & $163.74(2)$ & $160.59(2)$ & $159.75(2)$ \\
\hline $\mathrm{N} 20-\mathrm{M} 1-\mathrm{C} 15$ & $178.40(8)$ & $178.85(9)$ & $177.97(9)$ & $177.47(9)$ \\
\hline $\mathrm{M} 1-\mathrm{P} 2-\mathrm{C} 28$ & $104.27(8)$ & $104.11(9)$ & $107.05(10)$ & $106.58(10)$ \\
\hline
\end{tabular}

${ }^{a}$ Metrics associated with major disordered component $\left(1-C_{1}\right)$ only.

Structure of 1b @ $150 \mathrm{~K}$

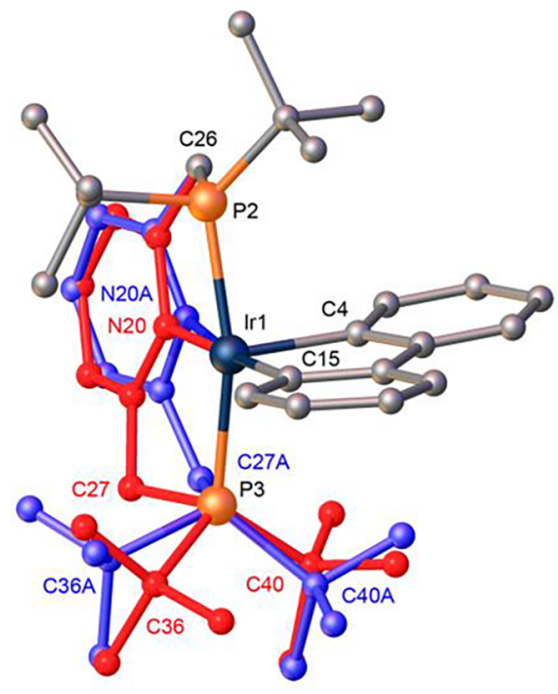

Disorder modelling

\begin{tabular}{|c|c|c|}
\hline$M$ & $T / \mathrm{K}$ & $1-C_{1}: 1-C_{s}$ \\
\hline $\mathrm{Rh}$ & 75 & $\begin{array}{c}\text { No significant } \\
\text { disorder }\end{array}$ \\
\hline $\mathrm{Rh}$ & 100 & $0.913(2): 0.087(2)$ \\
\hline $\mathrm{Rh}$ & 150 & $0.839(2): 0.161(2)$ \\
\hline $\mathrm{Rh}$ & 200 & $0.764(3): 0.236(3)$ \\
\hline $\mathrm{Rh}$ & 250 & $0.706(3): 0.294(3)$ \\
\hline Ir & 75 & $\begin{array}{l}\text { No significant } \\
\text { disorder }\end{array}$ \\
\hline Ir & 100 & $0.895(3): 0.105(3)$ \\
\hline Ir & 150 & $0.811(3): 0.189(3)$ \\
\hline Ir & 200 & $0.733(3): 0.267(3)$ \\
\hline Ir & 250 & $0.667(3): 0.333(3)$ \\
\hline
\end{tabular}

Van't Hoff analysis

Solid-state reaction

$1-C_{1} \rightleftharpoons 1-C_{s}$

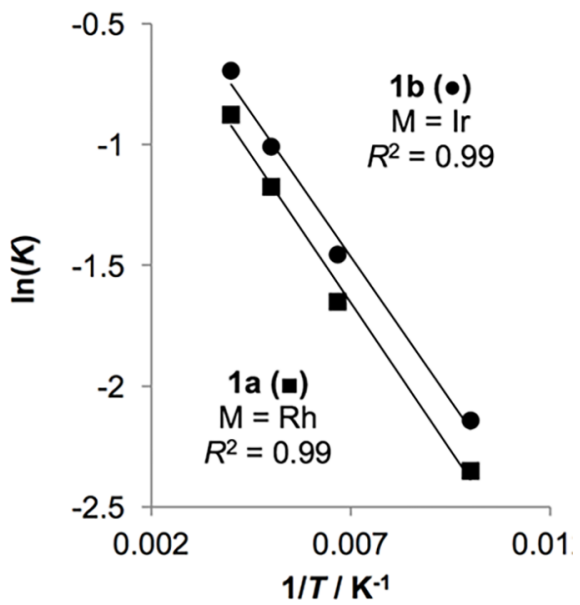

Figure 2. Solid-state dynamics of 1 interrogated by X-ray crystallography. 
modes is implicit, to the extent that these processes can even occur in the confined environment of a crystal lattice at cryogenic temperatures!

The solution-phase structure and dynamics of 1 and 2 were investigated in $\mathrm{CD}_{2} \mathrm{Cl}_{2}$ solution using multinuclear and variable-temperature NMR spectroscopy $(500 \mathrm{MHz}, 185-$ $308 \mathrm{~K})$. All complexes are markedly fluxional, with the dynamics notably manifested in ${ }^{1} \mathrm{H}$ NMR spectra measured at $298 \mathrm{~K}$ by line broadening of the biph, $\mathrm{CH}_{2}$ (PNP), and $t \mathrm{Bu}$ signals, with varying degrees of coalescence from overall $C_{s}$ to $C_{2 v}$ symmetry that we attribute to pseudorotation of the biph ligand on the NMR time scale. In the case of $1 \mathrm{a}$, the fast exchange regime was reached upon heating to $308 \mathrm{~K}$, resulting in a fully $C_{2 v}$ symmetric ${ }^{1} \mathrm{H}$ NMR spectrum, whereas cooling to $250 \mathrm{~K}$ resulted in a sharp $C_{s}$ symmetric ${ }^{1} \mathrm{H}$ NMR spectrum (Figure 3). Although full signal coalescence could not be
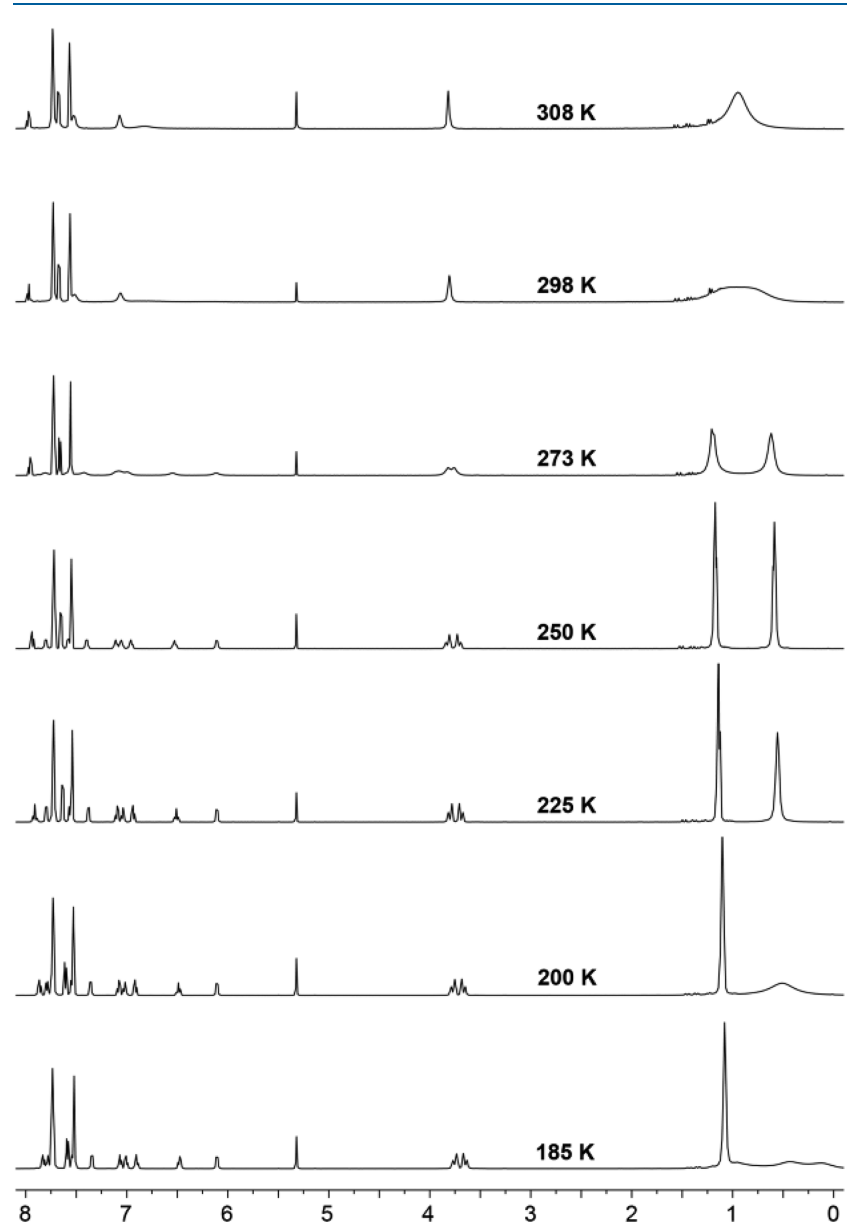

Figure 3. Variable-temperature ${ }^{1} \mathrm{H}$ NMR spectra of 1 a $\left(\mathrm{CD}_{2} \mathrm{Cl}_{2}, 500\right.$ $\mathrm{MHz}$ ).

achieved within the physical limits of the solvent for $\mathbf{1 b}$ or $\mathbf{2}$, simulation of the associated variable-temperature ${ }^{1} \mathrm{H}$ NMR spectra using gNMR enabled the activation parameters associated with the pseudorotation to be determined for all four complexes (Table 2). ${ }^{20}$ These data substantiate more facile pseudorotation in 1a compared to the other pincer complexes, which are notable for very similar activation barriers, $\Delta G^{\ddagger}$ ca. $60 \mathrm{~kJ} \mathrm{~mol}^{-1}$.

The measured activation barriers for the pseudorotation are well reproduced computationally at the $\omega \mathrm{B} 97 \mathrm{X}-\mathrm{D} 3$ level of theory (Table 2). For both pincer ligands, this rotation was
Table 2. Activation Barriers for the Pseudorotation Observed in 1 and 2 and Computational Models

\begin{tabular}{lllll}
$\Delta G^{\ddagger}\left(\mathrm{kJ} \mathrm{mol}^{-1}\right)$ & \multicolumn{1}{c}{$\mathbf{1 a}$} & \multicolumn{1}{c}{$\mathbf{1 b}$} & $\mathbf{2 a}$ & $\mathbf{2 b}$ \\
experiment & $56 \pm 1$ & $62 \pm 1$ & $58 \pm 4$ & $60 \pm 4$ \\
full model & 53.7 & 59.8 & 59.6 & 58.6 \\
truncated model & 21.2 & 21.7 & 20.4 & 18.2
\end{tabular}

found to proceed via distinctly $C_{2}$ symmetric trigonal bipyramidal transition states and relatively flat potential energy surfaces (absolute vibrational modes all $<40 \mathrm{~cm}^{-1}$ ). Adoption of the associated twisted pincer ligand geometries is necessary to minimize steric buttressing between tert-butyl substituents and the biph ligand, but these interactions are still significantly destabilizing. Supporting this assertion, the corresponding barriers for computational models featuring methyl instead of tert-butyl substituents are significantly lower (Table 2). Moreover, from the reported ${ }^{1} \mathrm{H}$ NMR data at ambient temperature $(400 \mathrm{MHz})$, the barrier associated with pseudorotation in $\mathbf{D}\left(C_{2 v}\right)$ is considerably less than for less sterically congested $\mathbf{C}\left(C_{s}\right){ }^{11}$

Overall, $C_{s}$ symmetry is retained in the ${ }^{1} \mathrm{H}$ NMR spectra of 1 and 2 in $\mathrm{CD}_{2} \mathrm{Cl}_{2}$ on cooling to $185 \mathrm{~K}$ and the ${ }^{31} \mathrm{P}\left\{{ }^{1} \mathrm{H}\right\} \mathrm{NMR}$ spectra of these complexes exhibit single sharp resonances across the full temperature range studied-1a, $\delta 44.2 ; 1 \mathbf{b}, \delta$ 27.0.; 2a, $\delta 179.8$; 2b, $\delta 157.7$ (298 K)-with those of the rhodium congeners notable for coupling to ${ }^{103} \mathrm{Rh}\left(\mathbf{1 a},{ }^{1} J_{\mathrm{RhP}}=\right.$ $\left.110 \mathrm{~Hz} ; 2 \mathrm{a},{ }^{1} J_{\mathrm{RhP}}=114 \mathrm{~Hz}\right)$. In the context of the pincer ligand conformations adopted in $\mathbf{1}$, these data do not enable us to definitely discriminate between time-averaged or static $C_{s}$ symmetric pincer binding, although on the basis of the dynamics observed in the solid state, the former is inferred. Cooling to low temperature does, however, impart the presence of restricted rotation in one of the two sets of tertbutyl groups (1a, $\Delta G^{\ddagger}=37 \pm 3 \mathrm{~kJ} \mathrm{~mol}^{-1}$; $1 \mathbf{b}, \Delta G^{\ddagger}=38 \pm 4 \mathrm{~kJ}$ $\left.\mathrm{mol}^{-1}\right)$. This hindered rotation could potentially be the manifestation of agostic bonding; however, none of the three decoalesced signals are shifted to appreciably low frequency and we correspondingly assign these tert-butyl groups to those proximal to the biph moiety. This assertion is supported by the observation of similar behavior in the carbonyl derivative 4 (vide infra).

The reactions of 1 and 2 with CO ( $1 \mathrm{~atm}$ ) were studied in $\mathrm{CD}_{2} \mathrm{Cl}_{2}$. Although sluggish, addition of $\mathrm{CO}$ occurs to the iridium pincers at ambient temperature, conferring carbonyl derivatives $3(t=6 \mathrm{~h})$ and $4(t=2$ days $)$ in quantitative

\section{Scheme 3. Reactions of 1 and 2 with $\mathrm{CO}^{a}$}
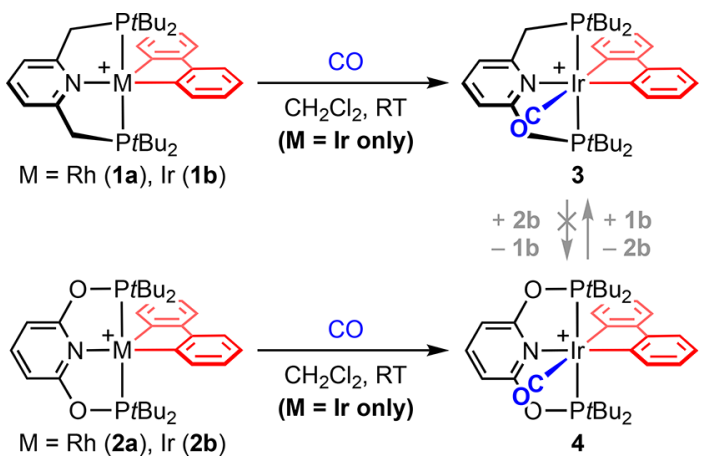

${ }^{a}\left[\mathrm{BAr}_{4}^{\mathrm{F}}\right]^{-}$counter anions omitted for clarity. 
spectroscopic yield $\left(3, \delta_{31 \mathrm{P}} 24.7 ; 4, \delta_{31 \mathrm{P}} 147.3\right.$; Scheme 3$)$. Both were subsequently isolated and fully characterized. No reactions resulted in the case of the lighter congeners, and this observation is borne out in the computationally derived thermodynamics, which indicates that the associated rhodium carbonyl derivatives are not formed with sufficiently exothermic enthalpies (cf. periodic trends apparent from Table 3) to offset the considerably unfavorable entropic

Table 3. Carbonyl Stretching Frequencies of PNP and PONOP Complexes $\left(\mathrm{CH}_{2} \mathrm{Cl}_{2}\right)$

\begin{tabular}{lc}
\multicolumn{1}{c}{ complex } & $\nu(\mathrm{CO})\left(\mathrm{cm}^{-1}\right)$ \\
{$[\mathrm{Rh}(\mathrm{PNP})(\mathrm{CO})]\left[\mathrm{BAr}_{4}^{\mathrm{F}}\right]$} & 1990 \\
{$[\mathrm{Rh}(\mathrm{PONOP})(\mathrm{CO})]\left[\mathrm{BAr}^{\mathrm{F}}{ }_{4}\right]$} & 2016 \\
{$[\operatorname{Ir}(\mathrm{PNP})(\mathrm{CO})]\left[\mathrm{BAr}^{\mathrm{F}}{ }_{4}\right]$} & 1977 \\
{$[\operatorname{Ir}(\mathrm{PONOP})(\mathrm{CO})]\left[\mathrm{BAr}_{4}^{\mathrm{F}}\right]$} & 2003 \\
3 & 2028 \\
4 & 2033 \\
\hline
\end{tabular}

penalties associated with reactions of this type (calculated $\Delta S$ ca. $-179 \mathrm{~J} \mathrm{~mol}^{-1} \mathrm{~K}^{-1} ;-298 \times \Delta S$ ca. $\left.+53 \mathrm{~kJ} \mathrm{~mol}^{-1}\right)$. Calculated $\Delta G_{298 \mathrm{~K}}$ values increase in the order $\mathbf{1 b}(-28.8 \mathrm{~kJ}$ $\left.\mathrm{mol}^{-1}\right)<2 \mathrm{~b}\left(-10.6 \mathrm{~kJ} \mathrm{~mol}^{-1}\right)<1 \mathrm{a}\left(+26.1 \mathrm{~kJ} \mathrm{~mol}^{-1}\right)<2 \mathrm{a}$ $\left(+47.5 \mathrm{~kJ} \mathrm{~mol}^{-1}\right)$, with the relative energetics of the iridium complexes confirmed by crossover experiments involving heating mixtures of $\mathbf{3} / \mathbf{2} \mathbf{b}$ (no reaction observed after 55 days at $50{ }^{\circ} \mathrm{C}$ ) and $\mathbf{4 / 1 b}$ (affords $\mathbf{3} / \mathbf{2 b}$ in $99 \%$ conversion after 55 days at $50{ }^{\circ} \mathrm{C}$ ).

The solid-state structure of $\mathbf{4}$ is notable for a significantly contorted metal coordination geometry compared to 3 , as gauged by significant deviation of the N20-Ir1-C15 angle from linearity $\left(163.83(9)^{\circ} \mathrm{cf} .173 .9(2)^{\circ}\right)$ and acute N20-Ir1C4 angle $\left(83.69(9)^{\circ}\right.$ cf. $94.2(2)^{\circ}$; Figure 4). This marked deviation from ideal geometry presumably results from steric congestion around the carbonyl ligand enforced by the rigid nature of the pincer backbone, and this suggestion is supported in solution by restricted rotation of the tert-butyl substituents proximal to the biph ligand on the ${ }^{1} \mathrm{H}$ NMR time scale $\left(\mathrm{CD}_{2} \mathrm{Cl}_{2}, 500 \mathrm{MHz} ; \Delta G^{\ddagger}=41 \pm 3 \mathrm{~kJ} \mathrm{~mol}^{-1}\right.$; assignment confirmed by a NOESY experiment). The carbonyl stretching band measured for $4\left(2033 \mathrm{~cm}^{-1}\right)$ is slightly elevated in comparison to that of $3\left(2028 \mathrm{~cm}^{-1}\right)$, but the variance is considerably less than that for the corresponding $\operatorname{Ir}(\mathrm{I})$ carbonyl pincers measured under the same conditions (Table 3). Combined, these data highlight the pivotal role of steric buttressing in the differences in thermodynamics and kinetics of carbonyl addition to PNP-ligated $\mathbf{1 b}$ compared to PONOPligated $\mathbf{2 b}$.

In the context of dynamics of the PNP pincer ligand, line broadening of the resonances associated with the phosphine donor groups that signals the onset of decoalescence from overall $C_{s}$ to $C_{1}$ symmetry (i.e., helical pincer binding) is apparent for 3 on cooling to low temperature (298 to $185 \mathrm{~K}$ ) by ${ }^{1} \mathrm{H}$ and ${ }^{31} \mathrm{P}$ NMR spectroscopy in $\mathrm{CD}_{2} \mathrm{Cl}_{2}$ solution $(500$ $\mathrm{MHz}$ ). This behavior indicates considerably less favorable pincer ligand dynamics in coordinatively saturated 3 in comparison to its unsaturated parent complex $\mathbf{1 b}$. Consistent with this suggestion, the $\mathrm{X}$-ray derived structure of $\mathbf{3}$ is notable for well-ordered helical coordination of the PNP ligand (within the error of the experiment) at $150 \mathrm{~K}$ (cf. 1b, vide supra).

\section{CONCLUSIONS}

Exploiting facile substitution reactions of $[\mathrm{Rh}(\mathrm{biph})(\mathrm{dtbpm})$ $\mathrm{Cl}]$ and $[\mathrm{Ir}(\mathrm{biph})(\mathrm{COD}) \mathrm{Cl}]_{2}$, the expedient and high-yielding synthesis of a homologous series of five-coordinate rhodium(III) and iridium(III) complexes of PNP (2,6$\left.\left(t \mathrm{Bu}_{2} \mathrm{PCH}_{2}\right)_{2} \mathrm{C}_{5} \mathrm{H}_{3} \mathrm{~N}\right)$ and PONOP $\left(2,6-\left(t \mathrm{Bu}_{2} \mathrm{PO}\right)_{2} \mathrm{C}_{5} \mathrm{H}_{3} \mathrm{~N}\right)$ pincer ligands has been described: $[\mathrm{M}(\mathrm{PNP})(\mathrm{biph})]\left[\mathrm{BAr}^{\mathrm{F}}{ }_{4}\right]$ $(\mathrm{M}=\mathrm{Rh}, \mathbf{1 a}$; Ir, $\mathbf{1 b})$ and $[\mathrm{M}(\mathrm{PONOP})(\mathrm{biph})]\left[\mathrm{BAr}^{\mathrm{F}}{ }_{4}\right](\mathrm{M}=$ $\mathrm{Rh}, \mathbf{2 a}$; Ir, 2b). These complexes display interesting structural dynamics in solution involving pseudorotation of the biph ligand on the ${ }^{1} \mathrm{H}$ NMR time scale $\left(\Delta G^{\ddagger}\right.$ ca. $\left.60 \mathrm{~kJ} \mathrm{~mol}^{-1}\right)$ and, in the case of the flexible PNP complexes, interconversion between helical and puckered pincer ligand conformations
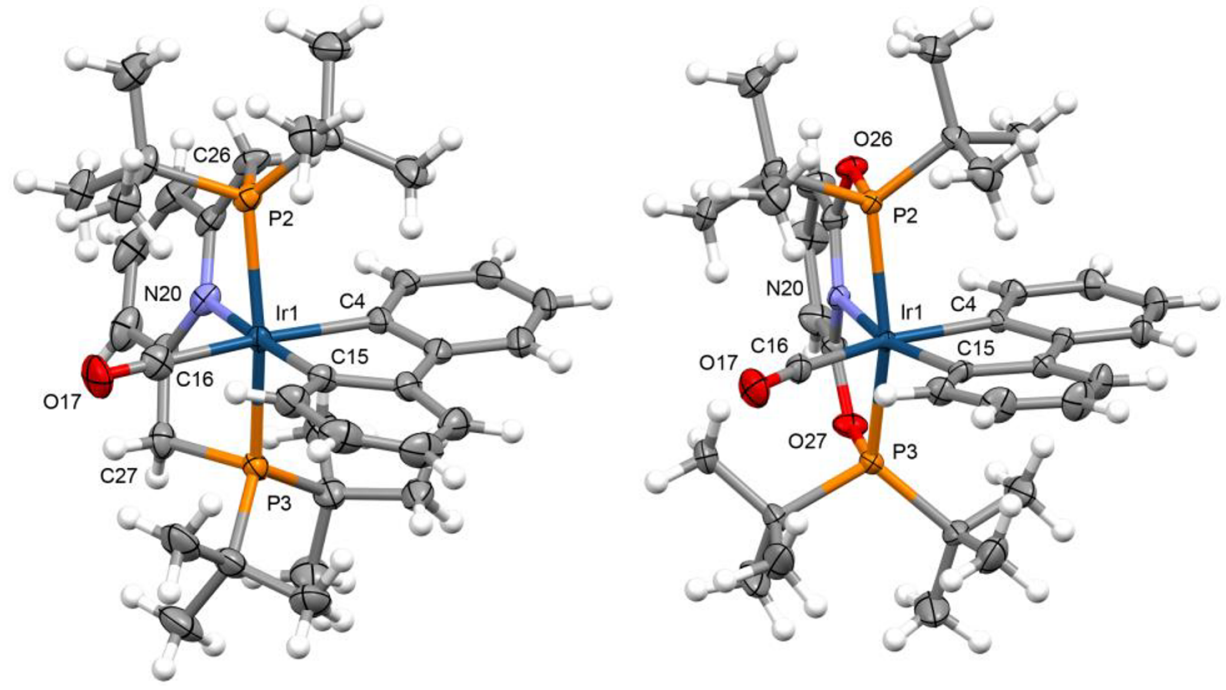

Figure 4. Solid-state structures of 3 (left) and 4 (right) determined at $150 \mathrm{~K}$. Thermal ellipsoids drawn at $50 \%$ probability; anions omitted. Selected bond lengths $(\AA)$ and angles (deg): 3, Ir1-P2, 2.3812(12); Ir1-P3, 2.4144(12); Ir1-C4, 2.110(4); Ir1-C15, 2.066(4); Ir1-C16, 1.927(5); Ir1-N20, 2.143(3); P2-Ir1-P3, 161.20(4); C4-Ir1-C16, 171.8(2); N20-Ir1-C15, 173.9(2); 4, Ir1-P2, 2.3644(6); Ir1-P3, 2.3828(6); Ir1-C4, 2.113(2); $\operatorname{Ir} 1-\mathrm{C} 15,2.085(2) ; \operatorname{Ir} 1-\mathrm{C} 16,1.920(3) ; \operatorname{Ir} 1-\mathrm{N} 20,2.128(2) ; \mathrm{P} 2-\operatorname{Ir} 1-\mathrm{P} 3,157.82(2) ; \mathrm{C} 4-\operatorname{Ir} 1-\mathrm{C} 16,166.78(10)$; N20-Ir1-C15, 163.83(9) 
$\left(\Delta G^{\ddagger}\right.$ ca. $\left.10 \mathrm{~kJ} \mathrm{~mol}^{-1}\right)$. Interrogation in silico suggests the former process involves overall $C_{2}$ symmetric transition states, with twisted PNP and PONOP pincer ligand binding geometries, that are significantly destabilized by steric buttressing between the tert-butyl phosphine substituents and the biph ligand. Remarkably, the latter process is sufficiently facile that it persists in the solid state, leading to temperaturedependent disorder in the associated X-ray crystal structures. Reaction of $\mathbf{1}$ and $\mathbf{2}$ with $\mathrm{CO}$ occurs for the iridium congeners $\mathbf{1 b}$ and $\mathbf{2 b}$, leading to the formation of sterically congested carbonyl derivatives.

\section{EXPERIMENTAL SECTION}

General Methods. All manipulations were performed under an atmosphere of argon using Schlenk and glovebox techniques unless otherwise stated. Glassware was oven-dried at $150{ }^{\circ} \mathrm{C}$ overnight and flame-dried under a vacuum prior to use. Molecular sieves were activated by heating at $300{ }^{\circ} \mathrm{C}$ in vacuo overnight. $\mathrm{CD}_{2} \mathrm{Cl}_{2}$ was freeze-pump-thaw degassed and dried over $3 \AA$ molecular sieves. Other anhydrous solvents were purchased from Acros Organics or Sigma-Aldrich, freeze-pump-thaw degassed, and stored over $3 \AA$ molecular sieves. PNP, ${ }^{21}$ PONOP, ${ }^{22} \mathrm{Na}\left[\mathrm{BAr}_{4}^{\mathrm{F}}\right],{ }^{14 \mathrm{c}}[\mathrm{Rh}(\mathrm{biph})-$ $(\mathrm{dtbpm}) \mathrm{Cl}]^{12 \mathrm{a}}$ and $[\mathrm{Ir}(\mathrm{biph})(\mathrm{COD}) \mathrm{Cl}]_{2},{ }^{12 \mathrm{~b}}$ and $[\mathrm{M}($ pincer $)(\mathrm{CO})]$ $\left[\mathrm{BAr}^{\mathrm{F}}{ }_{4}\right]^{17 \mathrm{a}, 23}$ were synthesized according to published procedures, or minor variations thereof. All other reagents are commercial products and were used as received. NMR spectra were recorded on Bruker spectrometers under argon at $298 \mathrm{~K}$ unless otherwise stated. Chemical shifts are quoted in ppm and coupling constants in Hz. ESI-MS were recorded on Bruker Maxis Plus (HR) or Agilent 6130B single Quad (LR) instruments. Infrared spectra were recorded on a PerkinElmer Spectrum 100 using a $\mathrm{KBr}$ transmission cell in $\mathrm{CH}_{2} \mathrm{Cl}_{2}$. Microanalyses were performed at the London Metropolitan University by Stephen Boyer.

Preparation of $[\mathrm{Rh}(\mathrm{PNP})(\mathrm{biph})]\left[\mathrm{BAr}_{4}{ }_{4}\right]$ (1a). A suspension of PNP $(87.9 \mathrm{mg}, 222 \mu \mathrm{mol}),[\mathrm{Rh}(\mathrm{biph})(\mathrm{dtbpm}) \mathrm{Cl}](132 \mathrm{mg}, 222$ $\mu \mathrm{mol})$, and $\mathrm{Na}\left[\mathrm{BAr}_{4}^{\mathrm{F}}\right](197 \mathrm{mg}, 222 \mu \mathrm{mol})$ in $\mathrm{CH}_{2} \mathrm{Cl}_{2}(2 \mathrm{~mL})$ was stirred at ambient temperature for $16 \mathrm{~h}$, filtered, and the filtrate reduced to dryness in vacuo. The resulting orange solid was washed with pentane and dried to give a microcrystalline orange solid. Yield: $293 \mathrm{mg}(87 \%)$. Single crystals suitable for X-ray diffraction were obtained by slow diffusion of pentane into a $\mathrm{CH}_{2} \mathrm{Cl}_{2}$ solution at ambient temperature.

${ }^{1} \mathrm{H}$ NMR (500 MHz, $\left.\mathrm{CD}_{2} \mathrm{Cl}_{2}\right): \delta 7.97\left(\mathrm{t},{ }^{3} \mathrm{~J}_{\mathrm{HH}}=7.8,1 \mathrm{H}, \mathrm{py}\right)$, $7.71-7.75\left(\mathrm{~m}, 8 \mathrm{H}, \mathrm{Ar}^{\mathrm{F}}\right), 7.67\left(\mathrm{~d},{ }^{3} \mathrm{~J}_{\mathrm{HH}}=7.8,2 \mathrm{H}, \mathrm{py}\right), 7.56(\mathrm{br}, 4 \mathrm{H}$, $\mathrm{Ar}^{\mathrm{F}}$ ), 7.52 (br, 2H, biph), 7.06 (br, 2H, biph), 5.8-7.3 (vbr m, 4H, biph), $3.81\left(\mathrm{br}, 4 \mathrm{H}, \mathrm{CH}_{2}\right), 1.07(\mathrm{vbr}, \mathrm{fwhm}=180 \mathrm{~Hz}, 18 \mathrm{H}, t \mathrm{Bu}), 0.81$ $(\mathrm{vbr}, \mathrm{fwhm}=180 \mathrm{~Hz}, 18 \mathrm{H}, \mathrm{tBu}$ ).

${ }^{13} \mathrm{C}\left\{{ }^{1} \mathrm{H}\right\}$ NMR $\left(126 \mathrm{MHz}, \mathrm{CD}_{2} \mathrm{Cl}_{2}\right.$, selected data only): $\delta 162.4$ (vt, $J_{\mathrm{PC}}=3, \mathrm{py}$ ), 140.9 (s, py), 123.4 (vt, $J_{\mathrm{PC}}=4, \mathrm{py}$ ), 36.3 (vt, $J_{\mathrm{PC}}=8$, $\left.\mathrm{CH}_{2}\right)$.

${ }^{31} \mathbf{P}\left\{{ }^{1} \mathbf{H}\right\}$ NMR $\left(202 \mathrm{MHz}, \mathrm{CD}_{2} \mathrm{Cl}_{2}\right): \delta 44.2\left(\mathrm{~d},{ }^{1} J_{\mathrm{Rhp}}=111\right)$.

HR ESI-MS (positive ion, $4 \mathrm{kV}): 650.2543,[\mathrm{M}]^{+}($calcd 650.2546) $m / z$.

Anal. Calcd for $\mathrm{C}_{67} \mathrm{H}_{63} \mathrm{BF}_{24} \mathrm{NP}_{2} \mathrm{Rh}\left(1513.87 \mathrm{~g} \mathrm{~mol}^{-1}\right)$ : C, 53.16; H, 4.19; N, 0.93; Found: C, 53.05; H, 4.17; N, 0.90.

Preparation of $[\operatorname{Ir}(\mathrm{PNP})(\mathrm{biph})]\left[\mathrm{BAr}_{4}\right]$ (1b). A suspension of PNP $(81.1 \mathrm{mg}, 205 \mu \mathrm{mol}),[\operatorname{Ir}(\mathrm{biph})(\mathrm{COD}) \mathrm{Cl}]_{2}(100 \mathrm{mg}, 103$ $\mu \mathrm{mol})$, and $\mathrm{Na}\left[\mathrm{BAr}_{4}^{\mathrm{F}}\right](182 \mathrm{mg}, 205 \mu \mathrm{mol})$ in $\mathrm{CH}_{2} \mathrm{Cl}_{2}(2 \mathrm{~mL})$ was stirred at ambient temperature for $16 \mathrm{~h}$, filtered, and the filtrate reduced to dryness in vacuo. The resulting red solid was washed with pentane and dried to give a microcrystalline red solid. Yield: $141 \mathrm{mg}$ (86\%). Single crystals suitable for X-ray diffraction were obtained by slow diffusion of pentane into a $\mathrm{CH}_{2} \mathrm{Cl}_{2}$ solution at ambient temperature.

${ }^{1} \mathrm{H}$ NMR $\left(500 \mathrm{MHz}, \mathrm{CD}_{2} \mathrm{Cl}_{2}\right): \delta 8.02\left(\mathrm{t},{ }^{3} J_{\mathrm{HH}}=7.9,1 \mathrm{H}, \mathrm{py}\right), 7.75$ $\left(\mathrm{d},{ }^{3} \mathrm{~J}_{\mathrm{HH}}=7.9,2 \mathrm{H}, \mathrm{py}\right), 7.71-7.80\left(\mathrm{~m}, 9 \mathrm{H}, \mathrm{Ar}^{\mathrm{F}}+\mathrm{biph}\right), 7.61(\mathrm{br}, 1 \mathrm{H}$, biph), $7.56\left(\mathrm{br}, 4 \mathrm{H}, \mathrm{Ar}^{\mathrm{F}}\right), 7.34$ (br, $1 \mathrm{H}$, biph), 7.07 (br, $2 \mathrm{H}, 2 \times$ biph), 6.88 (br, 1H, biph), 6.37 (br, 1H, biph), 5.80 (br, 1H, biph),
3.80 (vt, $J_{\mathrm{PH}}=4.1,4 \mathrm{H}, \mathrm{CH}_{2}$ ), $1.19($ br, $18 \mathrm{H}, t \mathrm{Bu}), 0.64$ (br, $18 \mathrm{H}$, $t \mathrm{Bu})$.

${ }^{13} \mathbf{C}\left\{{ }^{1} \mathbf{H}\right\}$ NMR (126 MHz, $\mathrm{CD}_{2} \mathrm{Cl}_{2}$, selected data only): $\delta 164.2$ (vt, $\left.J_{\mathrm{PC}}=3, \mathrm{py}\right), 140.3$ (s, py), $123.1\left(\mathrm{vt}, J_{\mathrm{PC}}=4, \mathrm{py}\right), 37.3$ (vt, $J_{\mathrm{PC}}=$ $11, \mathrm{CH}_{2}$ ), 30.6 (br, $\left.t \mathrm{Bu}\left\{\mathrm{CH}_{3}\right\}\right), 28.6$ (br, $\left.t \mathrm{Bu}\left\{\mathrm{CH}_{3}\right\}\right)$.

${ }^{31} \mathbf{P}\left\{{ }^{1} \mathbf{H}\right\}$ NMR $\left(202 \mathrm{MHz}, \mathrm{CD}_{2} \mathrm{Cl}_{2}\right): \delta 27.0$.

HR ESI-MS (positive ion, $4 \mathrm{kV}): 740.3110,[\mathrm{M}]^{+}($calcd 740.3122$)$ $m / z$.

Anal. Calcd for $\mathrm{C}_{67} \mathrm{H}_{63} \mathrm{BF}_{24} \mathrm{IrNP}_{2}\left(1603.18 \mathrm{~g} \mathrm{~mol}^{-1}\right)$ : C, 50.20; H, 3.96; N, 0.87; Found: C, 50.28; H, 3.88; N, 0.85 .

Preparation of $[\mathrm{Rh}(\mathrm{PONOP})(\mathrm{biph})]\left[\mathrm{BAr}_{4}{ }_{4}\right](2 \mathrm{a})$. A suspension of PONOP $(30.0 \mathrm{mg}, 75.1 \mu \mathrm{mol})$, [Rh(biph) $(\mathrm{dtbpm}) \mathrm{Cl}](44.6 \mathrm{mg}$, $75.0 \mu \mathrm{mol})$, and $\mathrm{Na}\left[\mathrm{BAr}_{4}^{\mathrm{F}}\right](66.6 \mathrm{mg}, 75.2 \mu \mathrm{mol})$ in $\mathrm{CH}_{2} \mathrm{Cl}_{2}(2 \mathrm{~mL})$ was stirred at ambient temperature for $16 \mathrm{~h}$, filtered, and the filtrate reduced to dryness in vacuo. The resulting orange solid was washed with pentane and dried to give a microcrystalline orange solid. Yield: $96.8 \mathrm{mg}(85 \%)$. Single crystals suitable for X-ray diffraction were obtained by slow diffusion of pentane into a $\mathrm{CH}_{2} \mathrm{Cl}_{2}$ solution at ambient temperature.

${ }^{1} \mathrm{H}$ NMR $\left(500 \mathrm{MHz}, \mathrm{CD}_{2} \mathrm{Cl}_{2}\right): \delta 8.14\left(\mathrm{t},{ }^{3} \mathrm{~J}_{\mathrm{HH}}=8.2,1 \mathrm{H}, \mathrm{py}\right)$, 7.70-7.77 (m, 9H $\mathrm{Ar}^{\mathrm{F}}+$ biph), 7.59 (br, 2H, biph), 7.56 (br, 4H, $\left.\mathrm{Ar}^{\mathrm{F}}\right), 7.20\left(\mathrm{~d},{ }^{3} J_{\mathrm{HH}}=8.2,2 \mathrm{H}, \mathrm{py}\right), 7.11(\mathrm{br}, 3 \mathrm{H}, 3 \times \mathrm{biph}), 6.54(\mathrm{vbr}$, fwhm $=120 \mathrm{~Hz}, 1 \mathrm{H}, \mathrm{biph}), 5.83(\mathrm{vbr}, \mathrm{fwhm}=95 \mathrm{~Hz}, 1 \mathrm{H}, \mathrm{biph}), 1.29$ (vbr, fwhm $=125 \mathrm{~Hz}, 18 \mathrm{H}, t \mathrm{Bu}), 0.79$ (vbr, fwhm $=125 \mathrm{~Hz}, 18 \mathrm{H}$, $t \mathrm{Bu})$.

${ }^{13} \mathbf{C}\left\{{ }^{1} \mathrm{H}\right\}$ NMR (126 MHz, $\mathrm{CD}_{2} \mathrm{Cl}_{2}$, selected data only): $\delta 162.3$ (vt, $\left.J_{\mathrm{PC}}=1, \mathrm{py}\right), 147.2(\mathrm{~s}, \mathrm{py}), 106.1$ (vt, $J_{\mathrm{PC}}=2$, py).

${ }^{31} \mathbf{P}\left\{{ }^{1} \mathrm{H}\right\}$ NMR $\left(202 \mathrm{MHz}, \mathrm{CD}_{2} \mathrm{Cl}_{2}\right): \delta 179.8\left(\mathrm{~d},{ }^{1} J_{\mathrm{RhP}}=114\right)$.

HR ESI-MS (positive ion, $4 \mathrm{kV}): 654.2128,[\mathrm{M}]^{+}($calcd 654.2132$)$ $m / z$.

Anal. Calcd for $\mathrm{C}_{65} \mathrm{H}_{59} \mathrm{BF}_{24} \mathrm{NO}_{2} \mathrm{P}_{2} \mathrm{Rh}\left(1517.82 \mathrm{~g} \mathrm{~mol}^{-1}\right)$ : C, 51.44; $\mathrm{H}, 3.92$; N, 0.92; Found: C, 51.23; H, 3.62; N, 0.90.

Preparation of $[\operatorname{Ir}(\mathrm{PONOP})(\mathrm{biph})]\left[\mathrm{BAr}{ }_{4}\right]$ (2b). A suspension of PONOP $(30.0 \mathrm{mg}, 75.1 \mu \mathrm{mol}),[\mathrm{Ir}(\mathrm{biph})(\mathrm{COD}) \mathrm{Cl}]_{2}(36.7 \mathrm{mg}, 37.6$ $\mu \mathrm{mol})$, and $\mathrm{Na}\left[\mathrm{BAr}_{4}^{\mathrm{F}}\right](66.6 \mathrm{mg}, 75.2 \mu \mathrm{mol})$ in $\mathrm{CH}_{2} \mathrm{Cl}_{2}(2 \mathrm{~mL})$ was stirred at ambient temperature for $16 \mathrm{~h}$, filtered, and the filtrate reduced to dryness in vacuo. The resulting red solid was washed with pentane and dried to give a microcrystalline red solid. Yield: $48.1 \mathrm{mg}$ (79\%). Single crystals suitable for X-ray diffraction were obtained by slow diffusion of pentane into a $\mathrm{CH}_{2} \mathrm{Cl}_{2}$ solution at ambient temperature.

${ }^{1} \mathbf{H}$ NMR (500 MHz, $\left.\mathrm{CD}_{2} \mathrm{Cl}_{2}\right): \delta 8.14\left(\mathrm{t},{ }^{3} J_{\mathrm{HH}}=8.2,1 \mathrm{H}, \mathrm{py}\right)$, 7.70-7.76 (m, 8H, Ar $\left.{ }^{\mathrm{F}}\right), 7.65(\mathrm{br}, 2 \mathrm{H}, 2 \times \mathrm{biph}), 7.56\left(\mathrm{br}, 4 \mathrm{H}, \mathrm{Ar}^{\mathrm{F}}\right)$, $7.42(\mathrm{br}, 1 \mathrm{H}, \mathrm{biph}), 7.28\left(\mathrm{~d},{ }^{3} \mathrm{~J}_{\mathrm{HH}}=8.2,2 \mathrm{H}, \mathrm{py}\right), 7.10(\mathrm{br}, 2 \mathrm{H}, 2 \times$ biph), 6.97 (br, 1H, biph), 6.33 (br, 1H, biph), 5.55 (br, 1H, biph), $1.28(\mathrm{br}, 18 \mathrm{H}, \mathrm{tBu}), 0.76(\mathrm{br}, 18 \mathrm{H}, t \mathrm{Bu})$.

${ }^{13} \mathrm{C}\left\{{ }^{1} \mathrm{H}\right\}$ NMR $\left(126 \mathrm{MHz}, \mathrm{CD}_{2} \mathrm{Cl}_{2}\right.$, selected data only): $\delta 162.9$ (br, py), 146.5 (s, py), 105.6 (vt, $J_{\mathrm{PC}}=2$, py), 28.8 (br, $t \mathrm{Bu}\left\{\mathrm{CH}_{3}\right\}$ ), 27.6 (br, $\left.t \mathrm{Bu}\left\{\mathrm{CH}_{3}\right\}\right)$.

${ }^{31} \mathbf{P}\left\{{ }^{1} \mathbf{H}\right\}$ NMR $\left(202 \mathrm{MHz}, \mathrm{CD}_{2} \mathrm{Cl}_{2}\right): \delta 157.7$.

HR ESI-MS (positive ion, $4 \mathrm{kV}): 744.2705,[\mathrm{M}]^{+}($calcd 744.2707$)$ $m / z$.

Anal. Calcd for $\mathrm{C}_{65} \mathrm{H}_{59} \mathrm{BF}_{24} \mathrm{IrNO}_{2} \mathrm{P}_{2}\left(1607.13 \mathrm{~g} \mathrm{~mol}^{-1}\right)$ : C, 48.58; H, 3.70; N, 0.87; Found: C, 48.36; H, 3.48; N, 0.88 .

NMR Scale Reactions of 1 and 2 with CO. A $20 \mathrm{mM}$ solution of $1 / 2$ in $\mathrm{CD}_{2} \mathrm{Cl}_{2}(0.5 \mathrm{~mL})$ prepared in a J. Young's valve NMR tube was freeze-pump-thaw degassed, placed under an atmosphere of carbon monoxide (1 atm), gently shaken at ambient temperature, and monitored periodically using ${ }^{1} \mathrm{H}$ and ${ }^{31} \mathrm{P}$ NMR spectroscopy. Quantitative conversion of $\mathbf{1 b}$ to $3(t=6 \mathrm{~h})$ and $2 \mathbf{b}$ to $4(t=2$ days) resulted. No reaction was observed in the case of $1 \mathbf{a}$ and $2 \mathrm{a}$ after $24 \mathrm{~h}$ (even after heating at $50{ }^{\circ} \mathrm{C}$ for an additional $24 \mathrm{~h}$ ).

Preparation of $[\operatorname{Ir}(\mathrm{PNP})(\mathrm{biph})(\mathrm{CO})]\left[\mathrm{BAr}_{4}\right]$ (3). A solution of $\mathbf{1 b}$ $(16.0 \mathrm{mg}, 9.98 \mu \mathrm{mol})$ in $\mathrm{CD}_{2} \mathrm{Cl}_{2}(0.5 \mathrm{~mL})$ was placed under an atmosphere of carbon monoxide $(1 \mathrm{~atm})$ and gently shaken for $6 \mathrm{~h}$ at ambient temperature (as above). The solvent was removed in vacuo to afford a white solid. Yield: $16.0 \mathrm{mg}$ (99\%). Single crystals suitable for X-ray diffraction were obtained by slow diffusion of hexane into a $\mathrm{CH}_{2} \mathrm{Cl}_{2}$ solution at ambient temperature. 
Table 4. Variable-Temperature ${ }^{1} \mathrm{H}$ NMR Data

\begin{tabular}{|c|c|c|c|c|c|c|c|c|}
\hline \multirow[b]{2}{*}{ complex } & \multirow[b]{2}{*}{ exchange } & \multicolumn{7}{|c|}{ rate of exchange $\left(\mathrm{s}^{-1}\right)$} \\
\hline & & $308 \mathrm{~K}$ & $298 \mathrm{~K}$ & $273 \mathrm{~K}$ & $250 \mathrm{~K}$ & $225 \mathrm{~K}$ & $200 \mathrm{~K}$ & $185 \mathrm{~K}$ \\
\hline 1a & biph & 2310 & 661 & 90 & 11 & & & \\
\hline 1a & $t \mathrm{Bu}$ & & & & & 4728 & 1008 & 266 \\
\hline $1 b$ & biph & 224 & 101 & 10 & 1 & & & \\
\hline $1 b$ & $t \mathrm{Bu}$ & & & & & 2554 & 297 & 205 \\
\hline $2 a$ & biph & 759 & 342 & 38 & 16 & & & \\
\hline $2 b$ & biph & 259 & 179 & 24 & 5 & & & \\
\hline 4 & $t \mathrm{Bu}$ & & & & & 1094 & 44 & 16 \\
\hline
\end{tabular}

${ }^{1} \mathrm{H}$ NMR $\left(500 \mathrm{MHz}, \mathrm{CD}_{2} \mathrm{Cl}_{2}\right): \delta 8.00\left(\mathrm{t},{ }^{3} J_{\mathrm{HH}}=7.9,1 \mathrm{H}, \mathrm{py}\right), 7.96$ $\left(\mathrm{d},{ }^{3} J_{\mathrm{HH}}=8.2,1 \mathrm{H}, \mathrm{biph}\right), 7.70-7.75\left(\mathrm{~m}, 8 \mathrm{H}, \mathrm{Ar}^{\mathrm{F}}\right), 7.68\left(\mathrm{~d},{ }^{3} J_{\mathrm{HH}}=7.9\right.$, $2 \mathrm{H}, \mathrm{py}), 7.62\left(\mathrm{~d},{ }^{3} \mathrm{~J}_{\mathrm{HH}}=7.6,1 \mathrm{H}, \mathrm{biph}\right), 7.58\left(\mathrm{~d},{ }^{3} J_{\mathrm{HH}}=7.9,1 \mathrm{H}, \mathrm{biph}\right)$, $7.56\left(\mathrm{br}, 4 \mathrm{H}, \mathrm{Ar}^{\mathrm{F}}\right), 7.12\left(\mathrm{t},{ }^{3} J_{\mathrm{HH}}=7.8,1 \mathrm{H}, \mathrm{biph}\right), 7.10\left(\mathrm{t},{ }^{3} J_{\mathrm{HH}}=7.9\right.$, $1 \mathrm{H}$, biph), $7.00\left(\mathrm{t},{ }^{3} J_{\mathrm{HH}}=7.4,1 \mathrm{H}, \mathrm{biph}\right), 6.91\left(\mathrm{t},{ }^{3} J_{\mathrm{HH}}=7.4,1 \mathrm{H}\right.$, biph), $6.81\left(\mathrm{~d},{ }^{3} J_{\mathrm{HH}}=7.5,1 \mathrm{H}, \mathrm{biph}\right), 4.30\left(\mathrm{dvt},{ }^{2} J_{\mathrm{HH}}=17.0, J_{\mathrm{PH}}=4.1\right.$, $\left.2 \mathrm{H}, \mathrm{CH}_{2}\right), 3.72\left(\mathrm{dvt},{ }^{2} J_{\mathrm{HH}}=17.0, J_{\mathrm{PH}}=3.5,2 \mathrm{H}, \mathrm{CH}_{2}\right), 1.27\left(\mathrm{vt}, J_{\mathrm{PH}}=\right.$ $7.2,18 \mathrm{H}, t \mathrm{Bu}$ ), 0.62 (vt, $J_{\mathrm{PH}}=7.4,18 \mathrm{H}, t \mathrm{Bu}$ ).

${ }^{13} \mathrm{C}\left\{{ }^{1} \mathrm{H}\right\}$ NMR $\left(126 \mathrm{MHz}, \mathrm{CD}_{2} \mathrm{Cl}_{2}\right): \delta 180.3\left(\mathrm{t},{ }^{2} J_{\mathrm{PC}}=7, \mathrm{CO}\right)$, $163.0(\mathrm{br}, \mathrm{py}), 162.3\left(\mathrm{q},{ }^{1} J_{\mathrm{CB}}=50, \mathrm{Ar}^{\mathrm{F}}\right), 159.5(\mathrm{~s}, \mathrm{biph}), 153.4(\mathrm{~s}$, biph), $141.8\left(\mathrm{t},{ }^{2} J_{\mathrm{PC}}=10\right.$, biph), 141.7 (s, py), 139.1 (s, biph), 137.5 (s, biph), $135.4\left(\mathrm{br}, \mathrm{Ar}^{\mathrm{F}}\right), 131.3\left(\mathrm{t},{ }^{2} J_{\mathrm{PC}}=6\right.$, biph $), 129.4\left(\mathrm{qq},{ }^{1} J_{\mathrm{FC}}=\right.$ $\left.32,{ }^{1} J_{\mathrm{CB}}=3, \operatorname{Ar}^{\mathrm{F}}\right), 128.2$ (s, biph), 126.7 (s, biph), 126.2 (s, biph), $125.2\left(\mathrm{q},{ }^{1} J_{\mathrm{FC}}=272, \mathrm{CF}_{3}\right), 124.7(\mathrm{~s}, \mathrm{biph}), 123.5\left(\mathrm{vt}, J_{\mathrm{PC}}=4, \mathrm{py}\right)$, 122.5 (s, biph), 122.1 (s, biph), $118.0\left(\right.$ sept, $\left.{ }^{3} J_{\mathrm{FC}}=4, \mathrm{Ar}^{\mathrm{F}}\right), 40.8(\mathrm{vt}$, $\left.J_{\mathrm{PC}}=10, t \mathrm{Bu}\{\mathrm{C}\}\right), 40.1\left(\mathrm{vt}, J_{\mathrm{PC}}=9, t \mathrm{Bu}\{\mathrm{C}\}\right), 40.0\left(\mathrm{vt}, J_{\mathrm{PC}}=11\right.$, $\mathrm{CH}_{2}$ ), 30.8 (br, $t \mathrm{Bu}\left\{\mathrm{CH}_{3}\right\}$ ), 30.2 (br, $\left.t \mathrm{Bu}\left\{\mathrm{CH}_{3}\right\}\right)$.

${ }^{31} \mathbf{P}\left\{{ }^{1} \mathbf{H}\right\}$ NMR $\left(162 \mathrm{MHz}, \mathrm{CD}_{2} \mathrm{Cl}_{2}\right): \delta 24.7$ $m / z$.

HR ESI-MS (positive ion, $4 \mathrm{kV}): 768.3064,[\mathrm{M}]^{+}($calcd 768.3072$)$

Anal. Calcd for $\mathrm{C}_{68} \mathrm{H}_{63} \mathrm{BF}_{24} \mathrm{IrNOP}_{2}\left(1631.19 \mathrm{~g} \mathrm{~mol}^{-1}\right)$ : C, 50.07; H, 3.89; N, 0.86; Found: C, 50.14; H, 3.74; N, 0.80 .

Preparation of [ $\operatorname{Ir}(\mathrm{PONOP})(\mathrm{biph})(\mathrm{CO})]\left[\mathrm{BAr}_{4}\right]$ (4). A solution of 2b $(16.1 \mathrm{mg}, 10.0 \mu \mathrm{mol})$ in $\mathrm{CD}_{2} \mathrm{Cl}_{2}(0.5 \mathrm{~mL})$ was placed under an atmosphere of carbon monoxide ( $1 \mathrm{~atm})$ and gently shaken for 2 days at ambient temperature (as above). The solvent was removed in vacuo to afford a white solid. Yield: $16.0 \mathrm{mg}$ (98\%). Single crystals suitable for $\mathrm{X}$-ray diffraction were obtained by slow diffusion of hexane into a $\mathrm{CH}_{2} \mathrm{Cl}_{2}$ solution at ambient temperature.

${ }^{1} \mathbf{H}$ NMR (500 MHz, $\left.\mathrm{CD}_{2} \mathrm{Cl}_{2}\right): \delta 8.13\left(\mathrm{t},{ }^{3} J_{\mathrm{HH}}=8.2,1 \mathrm{H}, \mathrm{py}\right), 7.97$ $\left(\mathrm{d},{ }^{3} \mathrm{~J}_{\mathrm{HH}}=7.7,1 \mathrm{H}, \mathrm{biph}\right), 7.67-7.78\left(\mathrm{~m}, 9 \mathrm{H}, \mathrm{Ar}^{\mathrm{F}}+\mathrm{biph}\right), 7.56(\mathrm{br}$, $\left.4 \mathrm{H}, \mathrm{Ar}^{\mathrm{F}}\right), 7.20\left(\mathrm{~d},{ }^{3} \mathrm{~J}_{\mathrm{HH}}=8.2,2 \mathrm{H}, \mathrm{py}\right), 7.18\left(\mathrm{~d},{ }^{3} \mathrm{~J}_{\mathrm{HH}}=7.2,1 \mathrm{H}, \mathrm{biph}\right)$, $7.12\left(\mathrm{t},{ }^{3} J_{\mathrm{HH}}=7.5,1 \mathrm{H}, \mathrm{biph}\right), 7.05\left(\mathrm{t},{ }^{3} J_{\mathrm{HH}}=7.6,1 \mathrm{H}, \mathrm{biph}\right), 6.75(\mathrm{t}$, $\left.{ }^{3} J_{\mathrm{HH}}=7.5,1 \mathrm{H}, \mathrm{biph}\right), 5.19\left(\mathrm{~d},{ }^{3} J_{\mathrm{HH}}=7.8,1 \mathrm{H}, \mathrm{biph}\right), 1.54\left(\mathrm{vt}, J_{\mathrm{PH}}=\right.$ 7.7, $18 \mathrm{H}, t \mathrm{Bu}$ ), 0.69 (vt, $J_{\mathrm{PH}}=8.5,18 \mathrm{H}, t \mathrm{Bu}$ ).

${ }^{13} \mathrm{C}\left\{{ }^{1} \mathrm{H}\right\}$ NMR (126 MHz, $\left.\mathrm{CD}_{2} \mathrm{Cl}_{2}\right): \delta 180.9\left(\mathrm{t},{ }^{2} J_{\mathrm{PC}}=9, \mathrm{CO}\right)$, 162.3 (br, py), $162.3\left(\mathrm{q}^{1} J_{\mathrm{CB}}=50, \mathrm{Ar}^{\mathrm{F}}\right), 156.5(\mathrm{~s}, \mathrm{biph}), 152.9(\mathrm{~s}$, biph), 147.5 (s, py), 143.2 (weak, biph), 135.4 (br, $\left.\mathrm{Ar}^{\mathrm{F}}+\mathrm{biph}\right), 134.5$ (s, biph), 129.7 (obscured, biph), $129.4\left(\mathrm{qq},{ }^{1} J_{\mathrm{FC}}=32,{ }^{1} J_{\mathrm{CB}}=3, \mathrm{Ar}^{\mathrm{F}}\right)$, 128.7 (s, biph), 128.0 (s, biph), 127.3 (s, biph), 125.8 (s, biph), 125.2 $\left(\mathrm{q},{ }^{1} J_{\mathrm{FC}}=272, \mathrm{CF}_{3}\right), 123.8(\mathrm{~s}, \mathrm{biph}), 123.4(\mathrm{~s}$, biph $), 118.0\left(\mathrm{sept},{ }^{3} J_{\mathrm{FC}}\right.$ $\left.=4, \mathrm{Ar}^{\mathrm{F}}\right), 106.0\left(\mathrm{vt}, J_{\mathrm{PC}}=2, \mathrm{py}\right), 46.4\left(\mathrm{vt}, J_{\mathrm{PC}}=9, t \mathrm{Bu}\{\mathrm{C}\}\right), 45.7$ (vt, $\left.J_{\mathrm{PC}}=9, t \mathrm{Bu}\{\mathrm{C}\}\right), 29.4$ (br, $\left.t \mathrm{Bu}\left\{\mathrm{CH}_{3}\right\}\right), 28.8$ (vt, $J_{\mathrm{PC}}=2, t \mathrm{Bu}\left\{\mathrm{CH}_{3}\right\}$ ).

${ }^{31} \mathbf{P}\left\{{ }^{1} \mathrm{H}\right\}$ NMR $\left(162 \mathrm{MHz}, \mathrm{CD}_{2} \mathrm{Cl}_{2}\right): \delta 147.3$.

HR ESI-MS (positive ion, $4 \mathrm{kV}): 772.2659,[\mathrm{M}]^{+}($calcd 772.2657$)$ $m / z$.

Anal. Calcd for $\mathrm{C}_{66} \mathrm{H}_{59} \mathrm{BF}_{24} \mathrm{IrNO}_{3} \mathrm{P}_{2}\left(1635.14 \mathrm{~g} \mathrm{~mol}^{-1}\right)$ : C, 48.48; H, 3.64; N, 0.86; Found: C, 48.42; H, 3.60; N, 0.89 .

Crossover Experiments. A solution of $1 \mathbf{b}(16.0 \mathrm{mg}, 9.98 \mu \mathrm{mol})$ and $4(16.4 \mathrm{mg}, 10.0 \mu \mathrm{mol})$ in $\mathrm{CD}_{2} \mathrm{Cl}_{2}(0.5 \mathrm{~mL})$ prepared in a $\mathrm{J}$. Young's valve NMR tube was heated at $50{ }^{\circ} \mathrm{C}$ and periodically monitored by ${ }^{1} \mathrm{H}$ and ${ }^{31} \mathrm{P}$ NMR spectroscopy. Slow conversion to $\mathbf{2 b}$ and $\mathbf{3}$ was observed, with a 99:1 mixture of $\mathbf{2 b}, \mathbf{3}: \mathbf{1} \mathbf{b}, \mathbf{4}$ obtained after 55 days.

A solution of $2 \mathbf{b}(16.1 \mathrm{mg}, 10.0 \mu \mathrm{mol})$ and $3(16.3 \mathrm{mg}, 10.0 \mu \mathrm{mol})$ in $\mathrm{CD}_{2} \mathrm{Cl}_{2}(0.5 \mathrm{~mL})$ prepared in a J. Young's valve NMR tube was heated at $50{ }^{\circ} \mathrm{C}$ and periodically monitored by ${ }^{1} \mathrm{H}$ and ${ }^{31} \mathrm{P}$ NMR spectroscopy. No reaction was apparent after 55 days.

Variable-Temperature NMR Experiments. Analysis was performed using $20 \mathrm{mM}$ solutions of the pincer complexes in $\mathrm{CD}_{2} \mathrm{Cl}_{2}(0.5 \mathrm{~mL})$ prepared in J. Young's valve NMR tubes. Samples were equilibrated at the required temperature for a period of $10 \mathrm{~min}$ before spectra were acquired $\left({ }^{1} \mathrm{H}, 500 \mathrm{MHz} ;{ }^{31} \mathrm{P}, 202 \mathrm{MHz}\right)$. Exchange processes observed by ${ }^{1} \mathrm{H}$ NMR spectroscopy were simulated using $\mathrm{gNMR}^{20}$ with reference line widths and values of $J_{\mathrm{PH}}$ fixed following analysis of low temperature data (Table 4, Supporting Information). Activation parameters were determined using the equation $\Delta G^{\ddagger}=R T\left[23.760+\ln \left(T / k_{\text {exchange }}\right)\right]$; reported values and errors are based on a statistical analysis of at least three different temperature points.

Crystallography. Data were collected on a Rigaku Oxford Diffraction SuperNova AtlasS2 CCD diffractometer using graphite monochromated $\mathrm{Mo} \mathrm{K} \alpha$ or $\mathrm{Cu} \mathrm{K} \alpha$ radiation and an Oxford Cryosystems N-HeliX cryostat. Data were collected and reduced using CrysAlisPro. ${ }^{24}$ The structures were solved using SHELXT and refined using SHELXL, through the Olex2 interface. ${ }^{25,26}$ All nonhydrogen atoms were refined anisotropically. Hydrogen atoms were placed in calculated positions and refined using the riding model.

Variable-temperature data for $\mathbf{1 a}$ and $\mathbf{1} \mathbf{b}$ were collected for unique crystals at $75,100,150,200$, and $250 \mathrm{~K}$ but in a nonsequential order. Samples were conditioned for at least $30 \mathrm{~min}$, with longer times for the lowest temperature measurements ( $1 \mathrm{~h} 45 \mathrm{~min}$ at $75 \mathrm{~K})$. No significant disorder was apparent from the refined data collected at 75 $\mathrm{K}$, with no Fourier peaks around the pincer methylene bridges $>0.7$ $\mathrm{e} \AA^{-3}$. Disorder of the pincer ligand at the other temperatures, evident from inspection of the thermal parameters and presence of Fourier peaks around the pincer methylene bridges $\geq 1.0 \mathrm{e}^{-3}$, was systematically treated by modeling part of the ligand over two sites and restraining its geometry (Figure 2). Rigid body constraints were applied for the pyridine moiety. In this way, the $R_{1}$ indices were significantly lowered (Supporting Information, Table S1) and sensible thermal parameters obtained in all cases.

Full details for all structures reported are documented in the CIF, which have been deposited with the Cambridge Crystallographic Data Centre under CCDC 1901989-1902010.

Computational. Starting from geometries of the cations observed in the solid state, optimizations were carried out using Grimme's dispersion corrected $\omega$ B97X-D3 functional ${ }^{19}$ as implemented in ORCA 4.0.1.2, with the def2-TZVPP basis set, and associated def2ECP on Rh/Ir, and the def2-TZVP(-f) basis set on all other atoms. ${ }^{27}$ Minima and saddle points were verified by analytical vibrational mode analysis at the same level of theory, which also provided thermochemical corrections. A scalar relativistic all-electron single point energy calculation was subsequently carried out using the $\omega \mathrm{B} 97 \mathrm{X}-\mathrm{D} 3$ functional within the ZORA approximation and using the corresponding basis sets (Rh, old-ZORA-TZVPP; Ir, SARC-ZORATZVPP; all other atoms, ZORA-def2-TZVP(-f) $).{ }^{28}$ NBO analyses were carried out using NBO 6.0. ${ }^{16}$ 


\section{ASSOCIATED CONTENT}

\section{S Supporting Information}

The Supporting Information is available free of charge on the ACS Publications website at DOI: 10.1021/acs.inorgchem.9b00957.

NMR, IR, and ESI-MS spectra of new compounds, NMR spectra of selected reactions, selected crystallographic parameters for $\mathbf{1 a}$ and $\mathbf{1 b}$ (Table S1), calculated thermodynamic values, and NBO analysis of $\mathbf{1}$ and $\mathbf{2}$ (PDF)

Optimized geometries (XYZ)

Primary NMR data (ZIP)

\section{Accession Codes}

CCDC 1901989-1902010 contain the supplementary crystallographic data for this paper. These data can be obtained free of charge via www.ccdc.cam.ac.uk/data_request/cif, or by emailing data_request@ccdc.cam.ac.uk, or by contacting The Cambridge Crystallographic Data Centre, 12 Union Road, Cambridge CB2 1EZ, UK; fax: +44 1223336033.

\section{AUTHOR INFORMATION}

\section{Corresponding Author}

*E-mail: a.b.chaplin@warwick.ac.uk.

\section{ORCID $\odot$}

Adrian B. Chaplin: 0000-0003-4286-8791

Notes

The authors declare no competing financial interest.

\section{ACKNOWLEDGMENTS}

We thank the European Research Council (ERC, grant agreement 637313) and Royal Society (UF100592, UF150675, A.B.C.) for financial support. High-resolution mass-spectrometry data were collected using instruments purchased through support from Advantage West Midlands and the European Regional Development Fund. Crystallographic data were collected using an instrument that received funding from the ERC under the European Union's Horizon 2020 research and innovation programme (Grant Agreement No. 637313). We thank Dr. C. André Ohlin for access to specialist computational resources.

\section{REFERENCES}

(1) (a) Pincer Compounds: Chemistry and Applications; MoralesMorales, D., Ed.; Elsevier: 2018; Vol. 1. (b) Kumar, A.; Bhatti, T. M.; Goldman, A. S. Dehydrogenation of Alkanes and Aliphatic Groups by Pincer-Ligated Metal Complexes. Chem. Rev. 2017, 117, 1235712384. (c) Andrew, R. E.; González-Sebastián, L.; Chaplin, A. B. NHC-Based Pincer Ligands: Carbenes with a Bite. Dalton Trans. 2016, 45, 1299-1305. (d) Organometallic Pincer Chemistry; van Koten, G., Milstein, D., Eds.; Topics in Organometallic Chemistry; Springer: 2013; Vol. 40. (e) van der Boom, M. E.; Milstein, D. Cyclometalated Phosphine-Based Pincer Complexes: Mechanistic Insight in Catalysis, Coordination, and Bond Activation. Chem. Rev. 2003, 103, 1759-1792. (f) Albrecht, M.; van Koten, G. Platinum Group Organometallics Based on "Pincer" Complexes: Sensors, Switches, and Catalysts. Angew. Chem., Int. Ed. 2001, 40, 3750-3781. (2) (a) Feller, M.; Diskin-Posner, Y.; Leitus, G.; Shimon, L. J. W.; Milstein, D. Direct Observation of Reductive Elimination of MeX (X $=\mathrm{Cl}, \mathrm{Br}, \mathrm{I})$ From $\mathrm{Rh}(\mathrm{III})$ Complexes: Mechanistic Insight and the Importance of Sterics. J. Am. Chem. Soc. 2013, 135, 11040-11047. (b) Feller, M.; Iron, M. A.; Shimon, L. J. W.; Diskin-Posner, Y.; Leitus, G.; Milstein, D. Competitive C-I Versus C-CN Reductive Elimination From a Rh(III) Complex. Selectivity Is Controlled by the
Solvent. J. Am. Chem. Soc. 2008, 130, 14374-14375. (c) Ben-Ari, E.; Cohen, R.; Gandelman, M.; Shimon, L. J. W.; Martin, J. M. L.; Milstein, D. ortho $\mathrm{C}-\mathrm{H}$ Activation of Haloarenes and Anisole by an Electron-Rich Iridium(I) Complex: Mechanism and Origin of Regioand Chemoselectivity. An Experimental and Theoretical Study. Organometallics 2006, 25, 3190-3210.

(3) (a) Adams, G. M.; Chadwick, F. M.; Pike, S. D.; Weller, A. S. A $\mathrm{CH}_{2} \mathrm{Cl}_{2}$ Complex of a $[\mathrm{Rh}(\text { Pincer })]^{+}$Cation. Dalton Trans. 2015, 44, 6340-6342. (b) Bernskoetter, W. H.; White, P. S.; Goldberg, K. I.; Brookhart, M. Investigations of Iridium-Mediated Reversible C-H Bond Cleavage: Characterization of a 16-Electron Iridium(III) Methyl Hydride Complex. J. Am. Chem. Soc. 2009, 131, 8603-8613. (c) BenAri, E.; Gandelman, M.; Rozenberg, H.; Shimon, L. J. W.; Milstein, D. Selective Ortho C-H Activation of Haloarenes by an $\operatorname{Ir}(\mathrm{I})$ System. J. Am. Chem. Soc. 2003, 125, 4714-4715.

(4) (a) Andrew, R. E.; Ferdani, D. W.; Ohlin, C. A.; Chaplin, A. B. Coordination Induced Atropisomerism in an NHC-Based Rhodium Macrocycle. Organometallics 2015, 34, 913-917. (b) Schultz, K. M.; Goldberg, K. I.; Gusev, D. G.; Heinekey, D. M. Synthesis, Structure, and Reactivity of Iridium NHC Pincer Complexes. Organometallics 2011, 30, 1429-1437. (c) Saito, S.; Azumaya, I.; Watarai, N.; Kawasaki, H.; Yamasaki, R. Synthesis, Structure and Catalytic Activity of Macrocyclic NHC Pd Pincer Complexes. Heterocycles 2009, 79, 531. (d) Hahn, F. E.; Jahnke, M. C.; Pape, T. Synthesis of PincerType Bis(Benzimidazolin-2-ylidene) Palladium Complexes and Their Application in C-C Coupling Reactions. Organometallics 2007, 26, 150-154. (e) Hahn, F. E.; Jahnke, M. C.; Gomez-Benitez, V.; Morales-Morales, D.; Pape, T. Synthesis and Catalytic Activity of Pincer-Type Bis(Benzimidazolin-2-ylidene) Palladium Complexes. Organometallics 2005, 24, 6458-6463. (f) Miecznikowski, J. R.; Gründemann, S.; Albrecht, M.; Mégret, C.; Clot, E.; Faller, J. W.; Eisenstein, O.; Crabtree, R. H. Outer Sphere Anion Participation Can Modify the Mechanism for Conformer Interconversion in Pd Pincer Complexes. Dalton Trans. 2003, No. 5, 831-838.

(5) For a notable example of PCP-ligand-based atropisomerism, see: Ma, L.; Woloszynek, R. A.; Chen, W.; Ren, T.; Protasiewicz, J. D. A New Twist on Pincer Ligands and Complexes. Organometallics 2006, $25,3301-3304$.

(6) (a) Findlater, M.; Schultz, K. M.; Bernskoetter, W. H.; Cartwright-Sykes, A.; Heinekey, D. M.; Brookhart, M. Dihydrogen Complexes of Iridium and Rhodium. Inorg. Chem. 2012, 51, 46724678. (b) Kloek, S. M.; Heinekey, D. M.; Goldberg, K. I. Stereoselective Decarbonylation of Methanol to Form a Stable Iridium(III) Trans-Dihydride Complex. Organometallics 2006, 25, 3007-3011.

(7) (a) Göttker-Schnetmann, I.; White, P. S.; Brookhart, M. Synthesis and Properties of Iridium Bis(phosphinite) Pincer Complexes ( $p$-XPCP) $\operatorname{IrH}_{2},(p$-XPCP $) \operatorname{Ir}(\mathrm{CO}),(p$-XPCP $) \operatorname{Ir}(\mathrm{H})($ Aryl $)$, and $\{(p-\mathrm{XPCP}) \operatorname{Ir}\}_{2}\left\{\mu-\mathrm{N}_{2}\right\}$ and Their Relevance in Alkane Transfer Dehydrogenation. Organometallics 2004, 23, 1766-1776. (b) Gupta, M.; Hagen, C.; Flesher, R. J.; Kaska, W. C.; Jensen, C. M. A Highly Active Alkane Dehydrogenation Catalyst: Stabilization of Dihydrido Rhodium and Iridium Complexes by a P-C-P Pincer Ligand. Chem. Commun. 1996, 2083-2084.

(8) (a) Storey, C. M.; Gyton, M. R.; Andrew, R. E.; Chaplin, A. B. Terminal Alkyne Coupling Reactions Through a Ring: Mechanistic Insights and Regiochemical Switching. Angew. Chem., Int. Ed. 2018, 57, 12003-12006. (b) Apps, S. L.; Alflatt, R. E.; Leforestier, B.; Storey, C. M.; Chaplin, A. B. Divergent Stereoisomers of Molybdenum Carbonyl Complexes of NHC-Based Pincer Ligands. Polyhedron 2018, 143, 57-61. (c) González-Sebastián, L.; Chaplin, A. B. Synthesis and Complexes of Imidazolinylidene-Based CCC Pincer Ligands. Inorg. Chim. Acta 2017, 460, 22-28. (d) Andrew, R. E.; Storey, C. M.; Chaplin, A. B. Well-Defined Coinage Metal Transfer Agents for the Synthesis of NHC-Based Nickel, Rhodium and Palladium Macrocycles. Dalton Trans. 2016, 45, 8937-8944. (e) Reference 4a. (f) Andrew, R. E.; Chaplin, A. B. Synthesis and Reactivity of NHC-Based Rhodium Macrocycles. Inorg. Chem. 2015, 54, 312-322. (g) Andrew, R. E.; Chaplin, A. B. Synthesis, Structure 
and Dynamics of NHC-Based Palladium Macrocycles. Dalton Trans. 2014, 43, 1413-1423.

(9) Gyton, M. R.; Leforestier, B.; Chaplin, A. B. Rhodium(III) and Iridium(III) Complexes of a NHC-Based Macrocycle: Persistent Weak Agostic Interactions and Reactions with Dihydrogen. Organometallics 2018, 37, 3963-3971.

(10) Laviska, D. A.; Zhou, T.; Kumar, A.; Emge, T. J.; KroghJespersen, K.; Goldman, A. S. Single and Double $\mathrm{C}-\mathrm{H}$ Activation of Biphenyl or Phenanthrene. an Example of $\mathrm{C}-\mathrm{H}$ Addition to $\mathrm{Ir}(\mathrm{III})$ More Facile Than Addition to Ir(I). Organometallics 2016, 35, 16131623.

(11) Laviska, D. A.; Guan, C.; Emge, T. J.; Wilklow-Marnell, M.; Brennessel, W. W.; Jones, W.; Jones, W. D.; Krogh-Jespersen, K.; Goldman, A. S. Addition of $\mathrm{C}-\mathrm{C}$ and $\mathrm{C}-\mathrm{H}$ Bonds by Pincer-Iridium Complexes: A Combined Experimental and Computational Study. Dalton Trans. 2014, 43, 16354-16365.

(12) (a) Iverson, C. N.; Jones, W. D. Rhodium-Catalyzed Activation and Functionalization of the $\mathrm{C}-\mathrm{C}$ Bond of Biphenylene. Organometallics 2001, 20, 5745-5750. (b) Lu, Z.; Jun, C.-H.; de Gala, S. R.; Sigalas, M. P.; Eisenstein, O.; Crabtree, R. H. Geometrically Distorted and Redox-Active Organometallic Iridium Complexes Containing Biphenyl-2,2'-diyl. Organometallics 1995, 14, 1168-1175.

(13) (a) Emerson-King, J.; Prokes, I.; Chaplin, A. B. Rhodium(III) Complexes Featuring Coordinated $\mathrm{CF}_{3}$ Appendages. Chem. - Eur. J. 2019, 25, 6317-6319. (b) Knighton, R. C.; Emerson-King, J.; Rourke, J. P.; Ohlin, C. A.; Chaplin, A. B. Solution, Solid-State, and Computational Analysis of Agostic Interactions in a Coherent Set of Low-Coordinate Rhodium(III) and Iridium(III) Complexes. Chem. Eur. J. 2018, 24, 4927-4938.

(14) (a) Martínez-Martínez, A. J.; Weller, A. S. Solvent-Free Anhydrous $\mathrm{Li}^{+}, \mathrm{Na}^{+}$and $\mathrm{K}^{+}$Salts of $\left[\mathrm{B}\left(3,5-\left(\mathrm{CF}_{3}\right)_{2} \mathrm{C}_{6} \mathrm{H}_{3}\right)_{4}\right]^{-}$, $\left[\mathrm{BAr}_{4}\right]^{-}$. Improved Synthesis and Solid-State Structures. Dalton Trans. 2019, 48, 3551-3554. (b) Yakelis, N. A.; Bergman, R. G. Safe Preparation and Purification of Sodium Tetrakis $[(3,5-$ Trifluoromethyl)Phenyl]Borate $\left(\mathrm{NaBArF}_{24}\right)$ : Reliable and Sensitive Analysis of Water in Solutions of Fluorinated Tetraarylborates. Organometallics 2005, 24, 3579-3581. (c) Buschmann, W. E.; Miller, J. S.; Bowman-James, K.; Miller, C. N. Synthesis of $\left[\mathrm{M}^{\mathrm{II}}(\mathrm{NCMe})_{6}\right]^{2+}$ $(\mathrm{M}=\mathrm{V}, \mathrm{Cr}, \mathrm{Mn}, \mathrm{Fe}, \mathrm{Co}, \mathrm{Ni})$ Salts of Tetra[3,5-bis(trifluoromethyl)phenyl]borate. Inorg. Synth. 2002, 33, 83-91.

(15) Brookhart, M.; Green, M. L. H.; Parkin, G. Agostic Interactions in Transition Metal Compounds. Proc. Natl. Acad. Sci. U. S. A. 2007, 104, 6908-6914.

(16) Glendening, E. D.; Badenhoop, J. K.; Reed, A. E.; Carpenter, J. E.; Bohmann, J. A.; Morales, C. M.; Landis, C. R.; Weinhold, F. NBO, v. 6.0; http://nbo6.chem.wisc.edu.

(17) (a) Gyton, M. R.; Hood, T. M.; Chaplin, A. B. A Convenient Method for the Generation of $\{\mathrm{Rh}(\mathrm{PNP})\}^{+}$and $\{\mathrm{Rh}(\mathrm{PONOP})\}^{+}$ Fragments: Reversible Formation of Vinylidene Derivatives. Dalton Trans. 2019, 48, 2877-2880. (b) Feller, M.; Ben-Ari, E.; Gupta, T.; Shimon, L. J. W.; Leitus, G.; Diskin-Posner, Y.; Weiner, L.; Milstein, D. Mononuclear $\mathrm{Rh}(\mathrm{II})$ PNP-Type Complexes. Structure and Reactivity. Inorg. Chem. 2007, 46, 10479-10490. (c) Feller, M.; Karton, A.; Leitus, G.; Martin, J. M. L.; Milstein, D. Selective $\mathrm{sp}^{3} \mathrm{C}-\mathrm{H}$ Activation of Ketones at the Beta Position by $\operatorname{Ir}(\mathrm{I})$. Origin of Regioselectivity and Water Effect. J. Am. Chem. Soc. 2006, 128, 12400-12401.

(18) (a) Chaplin, A. B.; Green, J. C.; Weller, A. S. C-C Activation in the Solid State in an Organometallic $\sigma$-Complex. J. Am. Chem. Soc. 2011, 133, 13162-13168. (b) Silvernail, N. J.; Barabanschikov, A.; Sage, J. T.; Noll, B. C.; Scheidt, W. R. Mapping NO Movements in Crystalline $[\mathrm{Fe}($ Porph)(NO)(1-MeIm)]. J. Am. Chem. Soc. 2009, 131, 2131-2140. (c) Braga, D. Dynamical Processes in Crystalline Organometallic Complexes. Chem. Rev. 1992, 92, 633-665.

(19) Lin, Y.-S.; Li, G.-D.; Mao, S.-P.; Chai, J.-D. Long-Range Corrected Hybrid Density Functionals with Improved Dispersion Corrections. J. Chem. Theory Comput. 2013, 9 (1), 263-272.

(20) $g N M R$, v. 4.1.2; Adept Scientific: Herts, U.K.
(21) Pelczar, E. M.; Emge, T. J.; Krogh-Jespersen, K.; Goldman, A. S. Unusual Structural and Spectroscopic Features of Some PNPPincer Complexes of Iron. Organometallics 2008, 27, 5759-5767.

(22) Bernskoetter, W. H.; Hanson, S. K.; Buzak, S. K.; Davis, Z.; White, P. S.; Swartz, R.; Goldberg, K. I.; Brookhart, M. Investigations of Iridium-Mediated Reversible $\mathrm{C}-\mathrm{H}$ Bond Cleavage: Characterization of a 16-Electron Iridium(III) Methyl Hydride Complex. J. Am. Chem. Soc. 2009, 131, 8603-8613.

(23) (a) Campos, J.; Kundu, S.; Pahls, D. R.; Brookhart, M.; Carmona, E.; Cundari, T. R. Mechanism of Hydrogenolysis of an Iridium-Methyl Bond: Evidence for a Methane Complex Intermediate. J. Am. Chem. Soc. 2013, 135, 1217-1220. (b) Kloek, S. M.; Heinekey, D. M.; Goldberg, K. I. Stereoselective Decarbonylation of Methanol to Form a Stable Iridium(III) trans-Dihydride Complex. Organometallics 2006, 25, 3007-3011.

(24) CrysAlisPro; Rigaku Oxford Diffraction: Yarnton, U.K.

(25) Sheldrick, G. M. Crystal structure refinement with SHELXL. Acta Crystallogr., Sect. C: Struct. Chem. 2015, C71, 3-8.

(26) Dolomanov, O. V.; Bourhis, L. J.; Gildea, R. J.; Howard, J. A. K.; Puschmann, H. OLEX2: a complete structure solution, refinement and analysis program. J. Appl. Crystallogr. 2009, 42, 339-341.

(27) (a) Neese, F. The ORCA Program System. Wiley Interdiscip. Rev. Comput. Mol. Sci. 2012, 2, 73-78. (b) Neese, F. Software Update: The ORCA Program System, Version 4.0. Wiley Interdiscip. Rev. Comput. Mol. Sci. 2018, 8, No. e1327. (c) Hill, J. G. Gaussian Basis Sets for Molecular Applications. Int. J. Quantum Chem. 2013, $113,21-34$.

(28) (a) Weigend, F.; Ahlrichs, R. Balanced Basis Sets of Split Valence, Triple Zeta Valence and Quadruple Zeta Valence Quality for $\mathrm{H}$ to Rn: Design and Assessment of Accuracy. Phys. Chem. Chem. Phys. 2005, 7, 3297-3305. (b) Pantazis, D. A.; Neese, F. All-Electron Scalar Relativistic Basis Sets for the Lanthanides. J. Chem. Theory Comput. 2009, 5, 2229-2238. (c) Pantazis, D. A.; Neese, F. AllElectron Scalar Relativistic Basis Sets for the 6p Elements. Theor. Chem. Acc. 2012, 131, 1292. (d) Pantazis, D. A.; Neese, F. AllElectron Scalar Relativistic Basis Sets for the Actinides. J. Chem. Theory Comput. 2011, 7, 677-684. (e) Pantazis, D. A.; Chen, X.-Y.; Landis, C. R.; Neese, F. All-Electron Scalar Relativistic Basis Sets for Third-Row Transition Metal Atoms. J. Chem. Theory Comput. 2008, 4, 908-919. 